\title{
Будущее ОБСЕ: подходы правительств
}

\author{
Под редакиией Франка Эверса и Аргиро Картсонаки*
}

\section{Аннотация}

В специальном выпуске OБCE Insights обсуждаются ожидания, которые правительства государств-участников ОБСЕ связывают с этой организацией. В статьях анализируются текущие позиции и политика восьми государств: США, России, Франции, Турции, Казахстана, Швеции, Польши и Северной Македонии. Авторы рассматривают также проблемы, которые накладывают ограничения на деятельность ОБСЕ, и предлагают пути дальнейшего развития. Специальный выпуск вносит вклад в обсуждение вопроса о том, как повысить значимость ОБСЕ во внешней политике ее государств-участников и эффективность самой организации в том, что касается достижения ее целей в преддверии предстоящего в 2025 г. 50-летнего юбилея ОБСЕ.

\section{Ключевые слова}

ОБСЕ, урегулирование конфликтов, внешняя политика, международные организации, мультилатерализм, права человека

Для цитирования этой публикации: Будущее ОБСЕ: подходы правительств / Ф. Эверс, А. Картсонаки (отв. ред.) // ОБСЕ Insights 5/2021. Специальный выпуск. - Баден-Баден: Номос, 2022. URL: https://doi.org/10.5771/9783748911463-05

* Франк Эверс

Институт исследований проблем мира и политики безопасности при Университете Гамбурга (IFSH), evers@ifsh.de

Аргиро Картсонаки

Институт исследований проблем мира и политики безопасности при Университете Гамбурга (IFSH), kartsonaki@ifsh.de. 


\section{Введение}

Франк Эверс и Аргиро Картсонаки

Несмотря на деградацию ситуации в сфере безопасности в регионе ОБСЕ, государства не используют возможности организации в полной мере. Почему? В специальном выпуске ОБСE Insights обсуждаются ожидания, которые отдельные государства-участники связывают с ОБСЕ в преддверии ее 50-летия в 2025 году. Предпринимается попытка выяснить, есть ли государства, которые намерены использовать организацию эффективнее, и как можно повысить ее значимость для них. В материалах данного выпуска анализируются подходы восьми государств-участников ОБСЕ. Некоторые из них - США и Россия - являются глобальными державами. Другие - Франция, Турция и Казахстан - играют важную роль в регионе. Четыре государства - бывший, нынешний и будущие Председатели организации: Казахстан (2010), Швеция (2021), Польша (2022) и Северная Македония (2023).

Авторам было предложено оценить место, которое отводится ОБСЕ в планирования внешней политики и политики безопасности соответствующих государств, в том числе в сравнении с другими международными организациями. В проведенных исследованиях анализируются ожидания, связываемые государствами-участниками с ОБСЕ, их планы по взаимодействию с ней и проблемы, которые ограничивают возможности организации. В некоторой степени в статьях нашли отражение взгляды представителей академических кругов и гражданского общества. Авторы констатируют, что ОБСЕ не находится в центре широких общественных дискуссий за стенами профильных ведомств. Наконец, в статьях представлены прогнозы или рекомендации относительно будущего взаимодействия соответствующих государств с ОБСЕ.

Многие авторы работали с правительствами своих стран в течение ряда лет. Это означает, с одной стороны, что они в какой-то мере являются инсайдерами, но с другой, - что некоторые из них не склонны быть особенно критичными по отношению к правительству. По этой причине в ряде статей преобладает изложение официальных подходов к отдельным вопросам. Некоторым темам уделяется меньше внимания, чем можно было бы ожидать. В этом смысле показательным является то, какие вопросы не поднимаются тем или иным автором.

Что касается источников, авторы в основном опирались на интервью с официальными лицами в своих странах и сотрудниками ОБСЕ, публичные заявления правительств и неопубликованные материалы текущего политического планирования. 


\section{Что показали исследования}

Представляя точку зрения Соединенных Штатов, Дэниел С. Гамильтон отмечает, что президенты страны до сих пор лишь эпизодически уделяли внимание ОБСЕ. Однако Конгресс США последовательно взаимодействует с организацией через Хельсинкскую комиссию, которая с 1976 г. проводит обсуждения проблематики ОБСЕ в Вашингтоне, а ее члены регулярно участвуют в работе делегации США в ОБСЕ в Вене. США неизменно поддерживают деятельность ОБСЕ на местах. Гамильтон утверждает, что для США ОБСЕ является инструментом продвижения интересов страны, особенно в области урегулирования конфликтов и защиты прав человека. Он прогнозирует, что администрация Байдена будет активнее участвовать в работе ОБСЕ, чем предыдущие администрации. США привержены всем трем измерениям деятельности организации и уделяют особое внимание таким темам, как контроль над обычными вооружениями, предотвращение и урегулирование конфликтов, защита прав человека и основных свобод, борьба с терроризмом и торговлей людьми. Что касается споров между США и Россией по вопросам военно-политической безопасности, неурегулированных конфликтов и прав человека, Гамильтон полагает, что «российско-американские консультации по вопросам стратегической стабильности могут быть дополнены аналогичным диалогом между государствами-участниками ОБСЕ».

Андрей Загорский представляет критику и ожидания России от ОБСЕ. В России считают, что Запад использует ОБСЕ как инструмент для вмешательства США, ЕС и НАТО во внутренние дела стран с целью навязывания им политических режимов западного типа. Москва критически относится к деятельности ОБСЕ в области человеческого измерения, считая ее предвзятой и устаревшей. Россия уже много лет предлагает преобразовать ОБСЕ в организацию, основанную на договоре, и вернуться к содержательным переговорам с целью «сверстать обновленную повестку дня» в отношениях между Россией и Западом. Что касается областей сотрудничества, то Россия отдает приоритет борьбе с транснациональными угрозами, такими как терроризм и организованная преступность, вызовы, порождаемые использованием информационно-коммуникационных технологий. Москва также видит потенциал для сотрудничества во втором измерении, особенно в том, что касается повестки дня в области торгово-транспортной взаимосвязанности.

Барбара Кунц констатирует противоречивое отношение Франции к ОБСЕ. С одной стороны, приверженность страны ОБСЕ проявляется в ее активном вкладе в повседневную деятельность организации и реализацию инициатив по урегулированию конфликтов. Будучи родиной Декларации прав человека и гражданина 1789 г., Франция чувствует особую ответственность за обеспечение прав человека. Париж использует свое участие в осуществляемой на высоком уровне деятельности ОБСЕ по урегулированию конфликтов, в частности, в качестве участника переговоров по Украине в рамках Нормандского формата и сопредседателя Минской группы по На- 
горному Карабаху для подтверждения своего статуса глобальной державы. С другой стороны, ОБСЕ не придается большое значение с точки зрения достижения важных для Франции внешнеполитических целей. Париж, по-видимому, считает, что в рамках многосторонних организаций, таких как ОБСЕ, невозможно быстро добиться конкретных результатов. Более того, «географический охват ОБСЕ не включает регионы, которые представляют наибольший интерес для Франции». Париж стремится к достижению своих целей либо на двусторонней основе, либо в рамках других многосторонних структур, тогда как его взаимодействие с ОБСЕ остается ограниченным. По этой причине Франция не готова взять на себя ведущую роль в организации или выступать с инициативами, которые позволили бы повысить ее эффективность.

Как и для большинства государств, политика которых анализируется в специальном выпуске, для Туриии наиболее важным измерением деятельности ОБСЕ является военно-политическое. Гирай Садык отмечает, что основной интерес Турции заключается в необходимости повысить эффективность деятельности ОБСЕ по стабилизации обстановки в кризисных зонах в непосредственной близости от страны, хотя при этом он не затрагивает вопрос о военной деятельности самой Турции в таких зонах. Он полагает, что ОБСЕ должна лучше использовать имеющиеся в ее распоряжении инструменты регулирования кризисов для содействия урегулированию затяжных конфликтов. Другими приоритетами Турции являются борьба с терроризмом и транснациональной организованной преступностью, особенно торговлей людьми, а также противодействие ксенофобии и исламофобии, имея в виду прежде всего проблемы, с которыми сталкивается турецкая диаспора в Европе. Отсутствие прогресса в этом вопросе является основным предметом критики Турции в адрес ОБСЕ. Не обсуждая внутренние проблемы страны, автор указывает на необходимость укрепления БДИПЧ, особенно в том, что касается мониторинга преступлений на почве ненависти и проблем интеграции мигрантов.

ОБСЕ занимает видное место в политической риторике Казахстана. Однако эта риторика не подкрепляется систематической деятельностью. Рустам Бурнашев и Ирина Черных отмечают, что взаимодействие Казахстана с ОБСЕ носит нерегулярный и преимущественно реактивный характер. Казахстан использует ОБСЕ как площадку для укрепления своего международного имиджа и демонстрации своих институциональных возможностей, как он это сделал во время председательства в ОБСЕ в 2010 г. Несмотря на декларативное признание важности ОБСЕ, власти страны воспринимают ее принципы и нормы как навязанные Казахстану извне. Они рассматривает ОБСЕ лишь как одну из многих европейских и евразийских организаций. Более того, они считают, что работающие в стране представители и эксперты ОБСЕ недостаточно хорошо понимают местные потребности, что отрицательно сказывается на планировании целесообразной деятельности на местах. Хотя свои ожидания власти Казахстана связывают в первую очередь с первым измерением ОБСЕ, они полагают, что деятельность в рамках второго измерения также может 
способствовать укреплению доверия и снижению напряженности в регионе. Казахстан стремится укрепить свой авторитет в этой области и, в частности, использует разногласия по поводу деятельности Офиса программ ОБСЕ в Нур-Султане для лоббирования открытия в стране тематического регионального центра ОБСЕ по устойчивой взаимосвязанности.

Ларс-Эрик Лундин представляет озабоченности и деятельность Швеции в качестве Председателя ОБСЕ в 2021 г. Шведское председательство сосредоточено на трех приоритетах: сохранение системы европейской безопасности, укрепление всеобъемлющего подхода к безопасности и содействие урегулированию конфликтов на основе политики «малых шагов». Одна из главных целей - «вернуться к основам», что предполагает необходимость, во-первых, обеспечить эффективное функционирование ОБСЕ и, во-вторых, - добиться соблюдения принципов ОБСЕ. Швеция делает акцент на уважении прав человека, рассматривая эту тему как комплексную проблему, непосредственно влияющую на два других измерения деятельности ОБСЕ. Швеция особенно обеспокоена эскалацией конфликтов к востоку от ее границ и военными угрозами для Швеции и Северной Европы. Учитывая это, Швеция стремится обеспечить свои интересы в сфере безопасности на основе сотрудничества с НАТО, членства в ЕС, солидарности со странами Северной Европы и поддержания особых отношений с США. На этом фоне Лундин отмечает, что Швеция видит возможность дополнить реализуемые страной меры оборонной политики реализацией согласованных в рамках ОБСЕ мер укрепления доверия и безопасности.

По словам Лукаша Кулесы, Польша - Председатель ОБСЕ в 2022 г. - также ощущает нарастание угроз на фоне событий к востоку от ее границ. Хотя Польша считает ОБСЕ важным звеном системы европейской безопасности, она отдает приоритет сотрудничеству и взаимодействию с другими международными организациями и политическими группировками, в частности, с НАТО и ЕС. Польское правительство считает, что эти две организации способны эффективнее обеспечить интересы страны в сфере внешней политики и политики безопасности, особенно когда речь идет о кризисах в Центральной и Восточной Европе. Кулеса отмечает, что главная ценность ОБСЕ для Польши заключается в том, что она представляет собой форум для поддержания диалога, «когда другие каналы коммуникации не работают или сильно ограничены». Таким образом, ОБСЕ, возможно, не в состоянии урегулировать существующие конфликты, но может стать открытой площадкой для поиска решений других проблем. По этой причине Польша намерена активно участвовать в работе ОБСЕ, что вписывается в ее стратегию поддержания многостороннего сотрудничества с целью укрепления стабильности в Европе. Эти соображения были для Варшавы одним из побудительных мотивов для того, чтобы предложить кандидатуру Польши в качестве Председателя ОБСЕ в 2022 г.

В своей статье о Северной Македонии, которая будет председательствовать в ОБСЕ в 2023 г., Ана Крстиновска констатирует, что в последние годы значимость ОБСЕ для этой страны снизилось по сравнению с другими организациями. Под- 
держка, оказываемая ОБСЕ проведению демократических реформ в Северной Македонии, позитивно воспринимается как внутри страны, так и в контексте ее международной интеграции. В то же время власти предпочитают отстаивать свои интересы в сфере «жесткой» безопасности с помощью не ОБСЕ, а НАТО. Взаимодействие Северной Македонии с ОБСЕ носит прагматический, а не стратегический характер. Она видит в ней организацию, которая поддерживает страну в достижении ее стратегических целей - вступления в ЕС и выполнения Целей ООН в области устойчивого развития. Северная Македония рассматривает председательство в ОБСЕ в 2023 г. как возможность продемонстрировать прогресс в построении демократических институтов и укрепить свой международный имидж.

\section{Заключение}

Ни одно из восьми государств, политика которых анализируется в специальном выпуске, не проявляет особую заинтересованность в расширении своего участия в деятельности ОБСЕ. Большинство государств не видят в ОБСЕ крупного игрока в сфере безопасности и предпочитают добиваться достижения своих внешнеполитических целей в рамках других организаций. Само по себе это неудивительно. Роль ОБСЕ снизилась в сравнении с другими международными организациями, и государства уже давно ставят под сомнение ее значимость в различных сферах и ситуациях.

В то же время все авторы отмечают заинтересованность в продолжении деятельности ОБСЕ. Этот вывод красной нитью проходит через все статьи сборника, особенно те, в которых анализируется политика государств-председателей. В статьях признается, что ОБСЕ предлагает открытое для всех пространство для диалога, в рамках которого проблемы безопасности могут быть вынесены на обсуждение без задержек и подготовительных переговоров. Таким образом, ОБСЕ рассматривается как важное звено многосторонних усилий по укреплению безопасности. В некоторых публикациях, особенно в тех, которые посвящены странам, расположенным по соседству с Россией, также отмечается, что в условиях нарастающего ощущения угрозы для их национальной безопасности деятельность ОБСЕ по обеспечению безопасности на основе сотрудничества считается важным дополнением проводимой ими политики сдерживания. Многие государства также видят необходимость в активизации деятельности организации по урегулированию конфликтов. Выводу о необходимости для ОБСЕ в большей степени следовать ориентированному на конкретные результаты подходу в процессе урегулирования затяжных конфликтов уделяется значительное внимание в большинстве статей, причем конфликты и другие споры в регионе не обязательно рассматриваются исключительно в контексте отношений между Западом и Россией. В то же время государства-участники не едины в ответе на вопрос о том, что ОБСЕ должна делать для защиты прав чело- 
века и следует ли ей вообще заниматься этим. Если одни государства хотели бы активизировать деятельность организации в данной области, то другие видят в этом навязывание чуждых им ценностей и вмешательство во внутренние дела. В этом нет ничего нового. В то же время мы читаем между строк, что некоторые государства ссылаются на необходимость решения проблем в рамках «человеческого измерения» в качестве предлога для достижения других целей их внутренней и внешней политики.

Выходя за рамки материалов специального выпуска, стоит поставить вопрос о том, заинтересованы ли государства-участники в сохранении ОБСЕ, и если да, то почему. Мы хотели бы обратить внимание на то, что, несмотря на второстепенную роль, которую ОБСЕ отводят государства, политика которых анализируется в специальном выпуске, ряд делегаций в Вене сегодня обсуждает вопрос о том, какую роль организация должна играть в обеспечении общей безопасности в Европе. По их мнению, многосторонний диалог вновь должен стать определяющим элементом отношений в сфере европейской безопасности, и на это необходимо обратить внимание лиц, принимающих решения в столицах государств-участников. В этой связи мы поддерживаем идею создания заинтересованными государствами неформальной «Группы друзей ОБСЕ» для обсуждения повестки дня прагматического сотрудничества в преддверии 50-летия ОБСЕ в 2025 г. 


\title{
Соединенные Штаты и ОБСЕ
}

\author{
Дэниел С. Гамильтон ${ }^{*}$
}

\section{Аннотаичя}

Подход США к ОБСЕ характеризуется спорадическим президентским вниманием, активной дипломатией на среднем уровне в самой организации и уникальным участием Конгресса США через Хельсинкскую комиссию. Администрация Байдена, похоже, пытается придать новый импульс отношениям США с ОБСЕ, в том числе в целях противостояния нетрадиционным угрозам безопасности, таким как агрессивные действия в киберпространстве и пандемия COVID-19. Для США ОБСЕ - не самоцель, а средство, с помощью которого можно продвигать свои политические интересы, в частности, с опорой на принципы, закрепленные в хельсинкском Заключительном акте 1975 года и парижской Хартии 1990 года.

\section{Введение}

Подход Соединенных Штатов (США) к ОБСЕ характеризуется спорадическим вниманием со стороны президентов, активной дипломатией на среднем уровне в самой организации и активным участием Конгресса США через Хельсинкскую комиссию. Администрация Байдена, похоже, пытается придать новый импульс отношениям США с ОБСЕ, в том числе в целях противостояния нетрадиционным угрозам безопасности, таким как агрессивные действия в киберпространстве и пандемия COVID-19. Для США ОБСЕ - не самоцель, а средство, с помощью которого можно продвигать свои политические интересы, в частности, с опорой на принципы, закрепленные в хельсинкском Заключительном акте 1975 года и парижской Хартии 1990 года.

\section{Нерегулярное внимание со стороны президентов}

Из всех президентов США наиболее активно взаимодействовал с ОБСЕ Билл Клинтон, о чем свидетельствует его участие в будапештском саммите 1994 года, на котором СБСЕ официально было преобразовано в ОБСЕ, и стамбульском саммите 1999 года. В то время, когда рухнула советская империя, а Советский Союз, Югославия и

* Дэниел С. Гамильтон

Международный научный центр им. Вудро Вильсона, dan.hamilton@wilsoncenter.org. 
Чехословакия распались на двадцать новых государств, многие из которых сталкивались с неурегулированными и зачастую порождавшими конфликты историческими обидами, территориальными и межэтническими спорами, президент Клинтон и его администрация исходили из того, что наибольшие угрозы для безопасности в Европе исходили от конфликтов как внутри государств, так и между ними. Администрация Клинтона полагала, что в этих условиях ОБСЕ могла внести уникальный вклад, поскольку в ее основе лежит принцип, согласно которому основная угроза для безопасности человека заключается в отрицании прав человека ${ }^{1}$.

Администрация Клинтона стремилась после «холодной войны» построить архитектуру европейской безопасности, в которой ОБСЕ могла бы стать организацией, вносящей свой вклад в урегулирование конфликтов, расширение и защиту демократии и демократических институтов, защиту прав человека, основных свобод и верховенства права, а также в выявление и решение экономических проблем, чреватых конфликтами и угрозами для безопасности на евразийско-евроатлантическом пространстве. К концу пребывания Клинтона у власти в 2000 году, пишет У. Хилл, «ОБСЕ по-настоящему расцвела, возможно, достигнув зенита своей деятельности и влияния» ${ }^{2}$, развернув на местах двадцать миссий и около 3000 сотрудников, прокладывая новые пути с помощью широкого и гибкого набора инструментов для предотвращения конфликтов, регулирования кризисов и постконфликтного восстановления.

После этого периода «построения архитектуры» президенты США стали уделять ОБСЕ намного меньше внимания. «Легкое пренебрежение» - так П.Т. Хопманн характеризовал отношение США к ОБСЕ на высшем уровне в период с 2001 по 2014 год ${ }^{3}$. Джордж Буш-младший после терактов 11 сентября 2001 года в основном сосредоточился на своей кампании борьбы с терроризмом, на войне в Ираке и на масштабном расширении НАТО. ОБСЕ в его расчетах не играла практически никакой роли. Барак Обама во время своего первого президентского срока также уделял мало внимания ОБСЕ, предпочитая доверять казавшийся относительно стабильным континент европейским союзникам и придавать меньшее значение американо-российским отношениям. Руководство США вновь обратило внимание на ОБСЕ только после незаконной аннексии Россией украинского полуострова Крым и ее вооруженной интервенции в восточной Украине, используя ОБСЕ и как площадку для осуждения нарушений Россией основных норм и принципов ОБСЕ, и как механизм для наблюдения и сдерживания действий России.

Низшая точка внимания президентов США к ОБСЕ пришлась на четырехлетний президентский срок Д. Трампа. Трамп пренебрегал организацией и открыто оспаривал основные принципы, закрепленные в парижской Хартии. Он поставил под сомнение важность прав человека как руководящего принципа внешней политики США и открыто пренебрегал важными для ОБСЕ приоритетами, будь то борьба с коррупцией, защита прав меньшинств или меры по укреплению доверия в военной сфере. Во время пребывания Трампа у власти Соединенные Штаты вышли из Дого- 
вора по открытому небу 1992 года, разработанного для улучшения взаимопонимания, укрепления доверия и содействия открытости и прозрачности вооруженных сил и их деятельности.

\section{Принципиальное дипломатическое взаимодействие}

Несмотря на нерегулярность внимания президентов к ОБСЕ, американские дипломаты настойчиво и решительно продвигали позиции страны по вопросам, стоящим в повестке дня ОБСЕ. Они отмечали ее ценность как единственной общеевропейской организации по безопасности, которая охватывает евроатлантический регион и участниками которой являются США, Канада, Россия, все европейские и центральноазиатские государства, а также Монголия. Американские дипломаты постоянно подчеркивают вклад ОБСЕ в укрепление военной безопасности в Европе на основе реализации охватывающего многочисленные сферы режима мер по укреплению доверия и транспарентности, процедур проверки и механизмов раннего предупреждения, которые помогли сократить военные арсеналы и снизить напряженность на большей части континента.

Американские дипломаты содействуют выполнению обязательств ОБСЕ по всем направлениям - в военно-политическом, экономическом, экологическом и человеческом измерениях. Это включает укрепление политической и военной безопасности во всем регионе ОБСЕ, выполнение и проверку соблюдения соглашений по контролю над вооружениями, укрепление возможностей ОБСЕ по предотвращению и урегулированию конфликтов, поддержку демократии, верховенства права и уважения прав человека и основных свобод, борьбу с такими угрозами безопасности, как терроризм, нетерпимость, дезинформация и торговля людьми, уделение большего внимания Центральной Азии и направление в регион бо́льших ресурсов. Официальные лица США настаивают на том, чтобы ОБСЕ стала более оперативной в этих областях. Они оказывают особую поддержку полевым миссиям организации и ее институтам. Представители администрации Байдена подчеркивают, что такая поддержка продолжится и в дальнейшем.

\section{Хельсинкская комиссия}

Рассказ о взаимодействии США с ОБСЕ был бы неполным без упоминания той важной роли, которую играет Конгресс США. Всего через год после подписания в 1975 году хельсинкского Заключительного акта Конгресс создал Комиссию по безопасности и сотрудничеству в Европе, более известную как Хельсинкская комиссия, для мониторинга и поддержки выполнения всех положений хельсинкского 
Заключительного акта. Комиссия двухпартийна и состоит из членов как Сената, так и Палаты представителей США, которых выбирают, соответственно, председатель Сената и спикер Палаты представителей. Еще три члена комиссии назначаются президентом США и представляют Государственный департамент, министерство обороны и министерство торговли. Впрочем, участие ветвей власти неравномерно. Комиссия явно управляется Конгрессом. Члены Конгресса неизменно занимают руководящие позиции в Парламентской ассамблее ОБСЕ с момента ее создания. У Соединенных Штатов самое большое представительство в Ассамблее - 17 из 323 мест. Хельсинкская комиссия имеет своего представителя за пределами США, в миссии США при ОБСЕ, что отражает уникальное сотрудничество между исполнительной и законодательной ветвями власти.

Хотя внимание комиссии распространяется на все сферы деятельности ОБСЕ, ее законодательный мандат предусматривает особое внимание к правам человека. Члены и сотрудники Хельсинкской комиссии входят в состав делегаций США на встречах ОБСЕ и участвуют в работе некоторых органов организации. Комиссия проводит общественные слушания и брифинги по вопросам повестки дня ОБСЕ с участием свидетелей-экспертов и издает публичные отчеты о выполнении государствами-участниками их обязательств по ОБСЕ. Она направляет официальные делегации в государства-участники и на встречи в рамках ОБСЕ для рассмотрения и оценки из первых рук событий, касающихся демократии, экономики, безопасности и прав человека. Комиссия регулярно привлекает внимание к проблемам в области прав человека и безопасности в государствах-участниках, включая расизм, антисемитизм, нетерпимость, коррупцию, торговлю людьми, отстаивание права на мирные собрания и ассоциации, защиту уязвимых сообществ, включая мигрантов, от дискриминации и насилия.

Комиссия особенно резко осуждала Россию, Беларусь, Турцию и ряд государств Центральной Азии не только за подавление инакомыслия в этих странах, но и за стремление подорвать работу ОБСЕ по защите основных свобод и ограничить участие гражданского общества в деятельности ОБСЕ. Комиссия сыграла центральную роль в разработке в 2012 году проекта «закона Магнитского», которым были введены санкции в отношении российских чиновников, ответственных за смерть российского юриста Сергея Магнитского в московской тюрьме в 2009 году, а также за другие нарушения прав человека и коррупцию. Председатель Хельсинкской комиссии, сенатор США Бен Кардин, принял активное участие в принятии «закона Магнитского», а в 2016 году - «Глобального закона Магнитского» об ответственности за нарушения прав человека, который президенты США от обеих партий использовали для введения санкций против коррупционеров по всему миру и который вдохновил принятие аналогичного законодательства в Канаде, Великобритании и Европейском союзе.

В 2021 году Хельсинкская комиссия США сосредоточилась на необходимости повышения роли Соединенных Штатов в деятельности по предотвращению массо- 
вых убийств, военных преступлений, преступлений против человечности и геноцида. Комиссия рассмотрела, какие признаки указывают на опасность совершения таких преступлений, и обсудила проблемы, препятствующие формированию устойчивых коалиций государств в целях предотвращения злодеяний. Она обратила внимание на угрозы для американских и глобальных цепочек поставок, создаваемые авторитарными режимами, и рекомендовала Парламентской ассамблее ОБСЕ одобрить инициативу «Безопасные цепочки поставок»- предложения по конкретным шагам, которые правительства государств-участников ОБСЕ могли бы предпринять в этой связи ${ }^{4}$.

Комиссия также проявила самокритичность в том, что касается выполнения США их обязательств по документам ОБСЕ. В 2020 году она провела серию придирчивых слушаний, посвященных «правам человека у себя дома». В ходе слушаний обсуждался, в частности, вопрос о том, как США могли бы продемонстрировать свою приверженность расовой справедливости, приняв соответствующие меры для защиты гражданских прав на свободу собраний и защиты журналистов. На слушаниях обсуждался также вопрос о роли общественных памятников и мемориалов, особенно тех, которые были возведены после Гражданской войны или в честь деятелей, связанных с расовыми притеснениями и рабством, а также мерах, направленных на восстановление исторической справедливости.

\section{Администрация Байдена и ОБСЕ}

Назначение президентом Байденом его близкого советника Майкла Карпентера послом в ОБСЕ - первый признак того, что нынешняя администрация будет проводить в ОБСЕ нацеленную на результаты энергичную политику. Всего через несколько недель после вступления президента в должность официальные лица воспользовались возможностью председательства США в Форуме ОБСЕ по сотрудничеству в области безопасности (ФСОБ), чтобы поставить вопрос о восстановлении прозрачности и доверия в военной сфере путем обновления Венского документа, который не пересматривался с 2011 года. Предлагаемые меры включают снижение порогов для уведомления и международного наблюдения за военными учениями, увеличение квот для проведения инспекций, расширение перечня категорий для включения в обмен информацией и пересмотр определения «необычной военной деятельности». Речь идет также о включении в повестку дня обсуждения военными представителями вопросов, касающихся последствий появления новых технологий, потенциально дестабилизирующих обстановку в области безопасности 5 . Представители США также добиваются активизации деятельности ОБСЕ по урегулированию затяжных конфликтов, достижения более конкретных результатов в экономической и экологической сфере, выступают за рассмотрение в ФСОБ выполнения резолюции Совета Безопасности ООН 1325 «Женщины, мир и безопасность», а также за прове- 
дение ОБСЕ в 2021 году Совещания по рассмотрению выполнения обязательств в области человеческого измерения.

Эти свидетельства активизации политики США сопровождаются осуждением действий России в Украине и других странах как основной причины значительного ухудшения обстановки в сфере европейской безопасности. Администрация Байдена будет и дальше противостоять вызывающим нарушениям Россией ее обязательств в рамках ОБСЕ, какими стали вооруженные интервенции в Грузии в 2008 году и в Украине в 2014 году. Официальные лица США призывают Россию выполнить минские обязательства в отношении Украины и заявляют, что Соединенные Штаты «никогда не признают претензию России на аннексию Крыма» ${ }^{6}$. Администрация Байдена поддерживает продолжение работы миссии ОБСЕ по наблюдению за пограничным режимом на двух российских контрольно-пропускных пунктах на границе с Украиной. Представители США регулярно подчеркивают, что Специальная мониторинговая миссия (CMM) в Украине имеет мандат на работу на всей территории Украины, включая Крым, и продолжают призывать Украину, Россию и силы, которые Россия вооружает, готовит, которыми она руководит и с которыми воюет бок о бок, обеспечить беспрепятственное передвижение СММ по всей территории Украины, а также гарантировать безопасность наблюдателей СММ. Они продолжают указывать на то, что силы Москвы также размещены в Молдове и Грузии без согласия этих стран и что использование Россией дезинформации и других гибридных методов — насущная проблема для всех стран ОБСЕ. Они также подчеркивают продолжающиеся нарушения прав человека и основных свобод в России в правление Путина, включая недавние меры по ограничению свободы слова и прессы путем значительного расширения сферы действия законодательства о так называемых «иностранных агентах», что делает отдельных журналистов уязвимыми для преследования и расширяет возможности государства по осуществлению цензуры.

В своей критике администрация Байдена не ограничивается Россией. Она говорит о несоблюдении обязательств по документам ОБСЕ и жестоком нарушении прав человека в Беларуси. Она требует от белорусских властей освободить политических заключенных, журналистов и всех тех, кто несправедливо задержан, и начать конструктивный диалог с Координационным советом оппозиции и гражданским обществом. Администрация и члены Хельсинкской комиссии решительно осудили принудительную посадку гражданского самолета в Беларуси для ареста белорусского активиста и журналиста Романа Протасевича и активистки гражданского общества Софии Сапеги. Хотя ситуация в Беларуси остается сложной, официальные лица США полагают, что ОБСЕ может повлиять на развитие ситуации, в частности, путем оказания Генеральным секретарем «добрых услуг». Представители США также обращают внимание на то, что некоторые государства используют COVID-19 как прикрытие для подавления гражданского общества и независимых СМИ, дальнейшего ограничения доступа общественности к информации и подрыва верховен- 
ства права. Вместе с Хельсинкской комиссией они пролили свет на преследование расовых, этнических и религиозных меньшинств, а также других уязвимых групп населения, таких как ЛГБТИ.

Администрация Байдена также проявляет интерес к тому, чтобы играть более активную роль в урегулировании нагорно-карабахского конфликта. Еще во время своей предвыборной кампании Байден обращал внимание на потенциальную роль ОБСЕ в наблюдении за тем, что происходит в зоне конфликта. Государственный секретарь Энтони Блинкен подчеркивает необходимость возобновления работы Минской группы ОБСЕ. Представители администрации призывают Армению и Азербайджан как можно скорее вернуться к предметным переговорам под эгидой сопредседателей Минской группы ОБСЕ (Россия, США, Франция) для достижения долгосрочного политического урегулирования, основанного на принципах хельсинкского Заключительного акта.

Заявления администрации США свидетельствуют также о намерении уделять больше внимания «второму измерению» ОБСЕ - экономическим и экологическим вопросам, - а также рассмотрению вопросов прогнозирования, предотвращения и, если необходимо, противостояния в будущем чрезвычайным ситуациям в области общественного здравоохранения и пандемиям. Представители США считают, что ОБСЕ может играть важную роль в решении проблем изменения климата в Центральной Азии и на Южном Кавказе. Они поддержали приоритетное рассмотрение вопросов изменения климата Швецией, председательствующей в ОБСЕ в 2021 году.

Наконец, в полном соответствии с решениями ОБСЕ, согласно которым коррупция представляет собой угрозу для безопасности, экономического развития и соблюдения прав человека, президент Байден включил борьбу с коррупцией в перечень «основных интересов национальной безопасности США». Он поручил правительству США провести межведомственный обзор для определения общегосударственной стратегии безопасности по борьбе с коррупцией. Хельсинкская комиссия приветствовала решение о проведении такого обзора и, вероятно, будет тесно сотрудничать с администрацией Байдена в его реализации.

\section{Заглядывая вперед: сценарии будущего}

Несмотря на то, что многие государства-участники не выполняют свои обязательства, принятые ими в рамках ОБСЕ, официальные лица США подчеркивают ценность организации и отмечают, что лучше работать над ее совершенствованием, чем отказаться от нее. Тем более что принципы хельсинкского Заключительного акта 1975 года и парижской Хартии 1990 года остаются важнейшими вехами в плане обязательств в рамках всеобъемлющего подхода, охватывающего военное, экономическое, экологическое и человеческое измерения безопасности. 
Есть несколько областей, в которых активизация взаимодействия США с ОБСЕ могла бы принести дивиденды ${ }^{7}$. Механизмы деконфликтинга, согласованные для предотвращения столкновений американских и российских сил в Сирии, могут послужить моделью для разработки под эгидой ОБСЕ аналогичных соглашений, связанных с воздушными и морскими спорами в Черном море и вокруг него. Ведущиеся в настоящее время двусторонние российско-американские консультации по вопросам стратегической стабильности могут быть дополнены аналогичным диалогом между государствами-участниками ОБСЕ. Вывод войск НАТО из Афганистана вызвал обеспокоенность стран Центральной Азии по поводу безопасности. США захотят изучить возможности для расширения деятельности ОБСЕ в этом регионе, возможно, включая развертывание здесь новых полевых миссий. ОБСЕ также может содействовать реализации некоторых трансграничных инициатив на Южном Кавказе, включая создание транспортного коридора Азербайджан-Армения-Турция. И хотя после вооруженного конфликта между Арменией и Азербайджаном осенью 2020 года ответственность за поддержание мира взяла на себя Россия, со временем Москва, возможно, не захочет нести эти расходы и бремя, что позволит учредить здесь многонациональную гражданскую мониторинговую миссию под эгидой ОБСЕ.

Сегодня общества на пространстве ОБСЕ сталкиваются с нетрадиционными вызовами безопасности, которые государства-участники не могли предвидеть, когда почти полвека назад собрались на беспрецедентное совещание, чтобы выработать принципы, которыми они должны руководствоваться в своих действиях ${ }^{8}$. Подрывные кибер-операции, дезинформация в социальных сетях, нарушения в цепочках поставок и пандемия COVID-19 наглядно продемонстрировали, что основные потоки людей, товаров, услуг, транспорта, продовольствия, денег и идей, которые питают общество, все больше подвержены сбоям. Растет потребность государствучастников ОБСЕ в определении принципов устойчивости, которые могли бы определять их действия в ситуациях, когда речь идет о предвидении, предотвращении и, если необходимо, защите от сбоев в осуществлении критически важных общественных функций. ОБСЕ остается площадкой, на которой представители государств, придерживающиеся разных взглядов, могут обсуждать правила поведения в таких остающихся относительно неисследованными сферах обеспечения безопасности, как устойчивость и взаимосвязанность, - если они решат это сделать. Если такого решения не будет, Соединенные Штаты и другие государства-участники определят эти правила в другом месте. 


\section{Примечания}

1 Пример такого подхода: Выступление президента США Билла Клинтона на открытии саммита ОБСЕ в Чираган Паласе Стамбул, Турция, 18 ноября 1999 г. См. также: Holbrooke R.C. America, a European Power// Foreign Affairs. 1995. March/April. URL: https://www.forei gnaffairs.com/articles/europe/1995-03-01/america-european-power.

2 Hill W. No Place for Russia: European Security Institutions Since 1989. - New York: Columbia University Press, 2019. P. 153.

3 Хопманн П.Т. Трамп, Путин и ОБСЕ // Ежегодник ОБСЕ 2018. - Гамбург: IFSH, 2020. - С. 51.

4 См.: The Ties That Bind: A Helsinki Commission Staff Report on Secure Supply Chains. US Helsinki Commission/Wilson Center, June 2021. URL: https://www.wilsoncenter.org/sites/defau lt/files/media/uploads/documents/Ties_that_Bind.pdf.

Почти все государства-участники ОБСЕ поддерживают такие усилия, однако Москва по-прежнему выступает против, а Армения и Азербайджан блокируют прогресс из-за вопросов, связанных с их двусторонними спорами.

6 Interpretative Statement on the Extension of the Mandate of the OSCE Special Monitoring Mission to Ukraine As prepared for delivery by Chargé d'Affaires Courtney Austrian to the Permanent Council, Vienna March 31, 2021 // U.S. Mission to the OSCE. URL: https://osce.usm ission.gov/interpretative-statement-on-the-extension-of-the-mandate-of-the-osce-special-monitor ing-mission-to-ukraine/; Statement by President Biden on the Anniversary of Russia's Illegal In vasion of Ukraine // The White House, 2021. 26 February. URL: https://www.whitehouse.gov/br iefing-room/statements-releases/2021/02/26/statement-by-president-biden-on-the-anniversary-of -russias-illegal-invasion-of-ukraine/.

7 О подходах США и Европы к будущей повестке дня ОБСЕ см.: Hamilton D.S. et al. Uncommon Cause: The Future of the OSCE. Report and Recommendations. Global Europe Program Working Group on the Future of the OSCE, February 2021. URL:

https:/www.wilsoncenter.org/sites/default/files/media/uploads/documents/Uncommon\%20Caus e\%20-\%20The\%20Future\%20of\%20the\%20OSCE\%20v2.pdf. Hamilton D.S. et al. Op. cit. 


\title{
Россия и ОБСЕ
}

\author{
Андрей Загорский*
}

\section{Аннотация}

На протяжении многих лет Москва критиковала ОБСЕ и пыталась ограничить деятельность организации на постсоветском пространстве. В то же время Москва не готова отказаться от нее. Россия исходит из необходимости пересмотреть географические и тематические приоритеты ОБСЕ и преобразовать ее в организацию, основанную на учредительном договоре. Возрождение чувства общности целей в ОБСЕ потребует комплексных переговоров, в ходе которых нельзя будет обойти стороной позиции, которые Россия считает принципиальными. И хотя время для достижения договоренности о новом статус-кво, наверно, еще не пришло, это не исключает возможность соглашения на основе модус вивенди. Такое соглашение могло бы быть достигнуто в ходе процесса «Хельсинки+50», в рамках которого предметом переговоров были бы, в частности, такие вопросы, как подготовка учредительного документа ОБСЕ, нахождение общего знаменателя между свободой выбора союзов и неделимостью безопасности, уточнение понимания принципов свободы СМИ и невмешательства во внутренние дела государств. ОБСЕ следует также стремиться к расширению пространства общих интересов государств-участников путем наращивания деятельности в наименее спорных областях, таких как противодействие новым (транснациональным) угрозам или преодоление последствий пандемии коронавируса.

\section{Введение}

Хуже, чем работать с ОБСЕ, может быть только одно: работать без ОБСЕ. Это выражение Черчилля, перефразированное применительно к теме статьи, как нельзя лучше отражает российские дискуссии на тему ОБСЕ. Москва достаточно сильна, чтобы помешать ОБСЕ делать то, что она считает нежелательным, но слишком слаба, чтобы добиться принятия в ОБСЕ российской повестки дня. Поэтому Москва на протяжении многих лет удерживает ОБСЕ в жестких рамках, настаивая на строгом применении правила консенсуса.

Это не означает, что Россия готова отказаться от ОБСЕ. Напротив, российские министры иностранных дел - в числе очень немногих министров государств-участ-

* Андрей Загорский

Национальный исследовательский институт мировой экономики и международных отношений имени Е.М. Примакова Российской академии наук (ИМЭМО РАН), Москва, zagorskiandrei@gmail.com. 
ников, постоянно участвующих в ежегодных встречах Совета министров. В определенных ситуациях ОБСЕ остается одной из немногих организаций, позволяющих России ограничить ущерб от ухудшения отношений с Западом. Это было особенно заметно на ранних стадиях кризиса в Украине. Россия также продолжает ценить сотрудничество между сопредседателями Минской группы, несмотря на то, что группа в 2020 г. не смогла остановить войну между Арменией и Азербайджаном из-за Нагорного Карабаха, и на нынешнюю неопределенность относительно ее дальнейшей роли в урегулировании конфликта.

Сложные отношения Российской Федерации с ОБСЕ и внутри нее восходят своими корнями к утраченному государствами-участниками ощущению общности целей, что проявилось в постоянных спорах по поводу тематических и географических приоритетов деятельности ОБСЕ в целом и ее структур и институтов в частности.

Первая часть настоящей статьи посвящена российской критике ОБСЕ и тому, что Москва не приветствует в деятельности организации. Во второй части рассматривается повестка дня, предлагаемая Россией в рамках ОБСЕ: что Москва ожидает от организации. В заключении сформулированы рекомендации относительно того, что можно было бы сделать в среднесрочной перспективе для сокращения разрыва в понимании государствами-участниками их общей цели.

\section{Критика в адрес ОБСЕ}

Критика ОБСЕ со стороны России имеет долгую историю. В 1999 году во время воздушных ударов НАТО в Югославии Россия обвинила ОБСЕ не только в неспособности обеспечить соблюдение ее принципов, но и в том, что она послужила прикрытием для этой операции 1 . Напряженность продолжала нарастать с началом в том же 1999 г. второй чеченской войны. В итоге в 2003 г. была свернута работа Группы содействия ОБСЕ в Чечне. Начиная с 2003 г. отношения с организацией омрачились критическими оценками российских выборов наблюдателями Бюро ОБСЕ по демократическим институтам и правам человека (БДИПЧ), а на фоне «цветных революций» в Восточной Европе ОБСЕ все больше воспринималась как агент «смены режимов» в соседних с Россией государствах, которую Москва стремилась не допустить.

В Москве высказывались опасения того, что доминирование НАТО в европейский системе безопасности сведет роль ОБСЕ к «демократизации европейской периферии», а увлечение оперативной деятельностью «слишком автономных» институтов ОБСЕ отодвинет на задний план задачи по поддержанию политического консенсуса на основе диалога ${ }^{2}$. В этом контексте был выдвинут тезис о географическом и тематическом дисбалансах в деятельности ОБСЕ, осуществлявшейся исключительно «к востоку от Вены» и преимущественно в сфере «человеческого из- 
мерения» ${ }^{3}$. С тех пор подчеркивание приоритетности политического диалога, необходимости устранения дисбалансов в деятельности ОБСЕ и сокращения автономии ее институтов остаются центральными в российской политике в ОБСЕ. В 2004 г. Болгария, будучи действующим Председателем ОБСЕ, предложила компенсировать сокращение деятельности организации в Центрально-Восточной и Юго-Восточной Европе расширением до тех пор скромной деятельности на постсоветском пространстве, прежде всего - в Центральной Азии и на Южном Кавказе. Именно этого не хотела Россия, поддержанная рядом государств-участников, в первую очередь членами Организации Договора о коллективной безопасности (ОДКБ).

Острые споры на встрече Совета министров в Софии в декабре 2004 года положили начало дискуссии о реформировании ОБСЕ, которая не завершилась до настоящего времени. Москва критически оценивает ОБСЕ как организацию, способствующую вмешательству США, ЕС и НАТО во внутренние дела государств, особенно постсоветских, с целью навязывания им политических режимов западного образца и установления прозападных правительств ${ }^{4}$. Президент Владимир Путин высказал эту критику следующим образом: «Такой важный механизм обеспечения общеевропейской, да и трансатлантической безопасности, как ОБСЕ, постоянно пытаются превратить в инструмент обслуживания чьих-то внешнеполитических интересов. И в результате этот важнейший инструмент работает вхолостую» ${ }^{5}$. Требование России об устранении дисбалансов в деятельности ОБСЕ не означает, что она считает, что организация должна расширить свою деятельность «к западу от Вены». Скорее, Россия считает, что ОБСЕ должна сократить свою деятельность, связанную с «человеческим измерением», на постсоветском пространстве. Вопрос о том, следует ли сократить ее или, по крайней мере, оставить на прежнем уровне, был одним из самых острых вопросов в ходе работы первой Группы видных деятелей ОБСЕ в 2005 г. ${ }^{6}$

Поскольку ни в 2004 г., ни в последующие годы Москва не смогла навязать ОБСЕ свою программу реформ, она обозначила жесткие рамки для ее деятельности, настаивая на строгом применении принципа консенсуса и проявляя большую придирчивость при обсуждении бюджета организации. Помимо этого Москва и ряд других постсоветских государств проводили политику одностороннего ограничения деятельности ОБСЕ, ставя под сомнение методы наблюдения БДИПЧ за выборами, понижая статус или прекращая присутствие ОБСЕ на своей территории или иным образом ограничивая ее деятельность в отдельных странах. Российская линия в целом сводилась к тому, что ОБСЕ должна реагировать на запросы принимающих правительств, а не продвигать свою собственную повестку дня, которую Россия воспринимала как западную. Москва считает, что не государства-участники должны следовать рекомендациям институтов ОБСЕ, а институты ОБСЕ должны адаптировать свою деятельность с учетом критики со стороны государств-участников ${ }^{7}$. 


\section{Российская повестка дня в ОБСЕ}

Российская повестка дня в ОБСЕ остается неизменной на протяжении последних полутора десятилетий. Ее можно свести к трем группам вопросов: возобновление предметного политического диалога, реформирование организации и пересмотр приоритетных направлений деятельности ОБСЕ.

\section{Возобновление предметного диалога}

Главный пункт современной российской повестки дня в отношении ОБСЕ - возобновление предметного диалога в рамках организации без предварительных условий (это относится также к НАТО и ЕС). Москва исходит из того, что такой диалог должен учитывать российские озабоченности и способствовать прогрессу в обсуждении вопросов, которые она ставит в организации на протяжении последних лет. Среди них: подтверждение принципа неделимости безопасности в противовес свободе выбора союзов, устранение дисбалансов в деятельности ОБСЕ и реформирование организации, в том числе - ограничение «чрезмерной автономии» ее институтов. В ходе диалога России и Западу предстоит найти общий знаменатель на основе разумного компромисса, «сверстать обновленную повестку дня, сфокусироваться на том, что нас объединяет, а не разъединяет», как эту задачу сформулировал министр иностранных дел России Сергей Лавров (выделено автором) ${ }^{8}$.

В Москве рассматривали как многообещающий организованный в 2013 и 2014 гг. на площадке ОБСЕ диалог «Хельсинки $+40 »$. Считалось, что он мог бы привести к корректировке деятельности ОБСЕ. Однако он был прерван кризисом в Украине. Москва приветствовала бы возобновление этого процесса в виде диалога «Хельсинки+50», целью которого стало бы достижение содержательного соглашения по повестке дня и приоритетам ОБСЕ, которое могло бы быть принято в 2025 году на встрече высокого уровня, посвященной 50-летию хельсинкского Заключительного акта. Однако мало кто, если вообще кто-либо из российских официальных лиц считает, что это осуществимо в нынешних условия ${ }^{9}$.

\section{Реформирование ОБСЕ}

С 2004 года Россия выдвигает предложения о преобразовании ОБСЕ в международную организацию со своим уставом. Согласно этим предложениям, государстваучастники участвовали бы в работе организации в индивидуальном качестве, а не в составе какой-либо группы стран. Автономные институты ОБСЕ предлагалось интегрировать в секретариат, а их деятельность осуществлялась бы строго в соответ- 
ствии с принятыми на основе консенсуса политическими указаниями директивных органов ОБСЕ. Наблюдение за выборами регулировалось бы специальным регламентом. В основе этих предложений лежит необходимость принятия устава или учредительного документа, который регулировал бы деятельность исполнительных институтов и структур ОБСЕ ${ }^{10}$. Хотя в ходе обсуждений российские предложения не были поддержаны в организации, Москва продолжает усилия в этом направлении. На встрече Совета министров 2020 г. в Тиране Лавров вновь призвал к проведению реформы и предложил учредить с этой целью неформальную рабочую группу по повышению эффективности ОБСЕ ${ }^{11}$. В феврале 2021 г. он передал действующему Председателю ОБСЕ, министру иностранных дел Швеции Анн Линде неофициальный документ с изложением российских предложений относительно обсуждения данного вопроса ${ }^{12}$.

\section{Определение приоритетных областей сотрудничества ${ }^{13}$}

Предложения Москвы относительно конкретных областей, в которых государстваучастники ОБСЕ должны стремиться к сотрудничеству, включают новые (транснацинональные) угрозы, такие как международный терроризм, незаконный оборот наркотиков, вызовы, порождаемые использованием информационно-коммуникационных технологий, торговля людьми и другие виды трансграничной организованной преступной деятельности. Москва также ожидает от ОБСЕ вклада в преодоление последствий пандемии коронавируса. В частности, Россия предлагает дополнить мандат Бюро Координатора экономической и экологической деятельности ОБСЕ задачами по укреплению научно-технического сотрудничества в области медицины и здравоохранения ${ }^{14}$.

Если необходимость сотрудничества по противодействию новым угрозам для безопасности не вызывает в ОБСЕ острых споров, то другие российские приоритеты касаются вопросов, которые находятся в центре риторического противостояния между Россией и Западом. Один из примеров - защита прав национальных меньшинств. Россия делает акцент на языковых и образовательных правах русских меньшинств в Украине и странах Балтии, а также на продвижении социальных и экономических, а не политических и гражданских прав. Поддерживая дискуссию о свободе информации, Москва делает акцент на необходимости противодействия ограничению деятельности российских СМИ и журналистов в Украине и на Западе. Москва по-прежнему критически относится к деятельности ОБСЕ в области «человеческого измерения», утверждая, что она не только политически предвзята, но и устарела с учетом того, что все государства-участники являются членами ООН

и, следовательно, сотрудничают с Советом ООН по правам человека. Кроме того, большинство государств-участников являются членами Совета Европы и охвачены его интрузивным механизмом защиты прав человека. Это - один из аргументов, 
которые Россия приводит в поддержку своей давней политики, согласно которой ОБСЕ следует сократить свою деятельность в области «человеческого измерения», особенно в постсоветских странах, а не расширять ее на Западе.

Что касается «конфликтного цикла», российский подход заключается в том, что любые меры, которые могла бы предпринимать ОБСЕ, должны обсуждаться в каждом конкретном случае, а решения по ним должны приниматься в Постоянном совете на основе консенсуса при условии согласия принимающей страны. В целом же Москва стремится сохранить статус-кво в обсуждаемых конфликтах. Она ожидает от ОБСЕ содействия в консолидации режима прекращения огня в Нагорном Карабахе, согласованного при посредничестве России; приветствует участие ОБСЕ в Международных женевских дискуссиях с участием Грузии, Абхазии и Южной Осетии; считает необходимым придать дополнительную динамику переговорам в формате «5+2» в рамках приднестровского урегулирования (Молдова). Москва подчеркивает, что ОБСЕ следует более последовательно оказывать давление на Украину, чтобы добиться выполнения ею Минских соглашений по урегулированию конфликта на востоке страны $^{15}$.

ОБСЕ остается вне поля зрения России в том, что касается безопасности в Центральной Азии: рисков распространения терроризма, наркоторговли и региональной дестабилизации, исходящих из Афганистана. Противодействие этим рискам обсуждалось Москвой в рамках двусторонних и многосторонних консультаций с участием соответствующих стран, в частности, США, Китая, Пакистана, Индии, Ирана, государств Центральной Азии, а также внутриафганских сил, включая талибов. В то же время Россия укрепляет сотрудничество в рамках ОДКБ в качестве страховки от возможных последствий прихода талибов к власти в Афганистане. В этом контексте она ожидает от ОБСЕ дальнейшего развития институционального сотрудничества с ОДКБ.

Россия традиционно подчеркивает важность экономико-экологического измерения ОБСЕ. Помимо участия в обсуждении темы торгово-транспортной взаимосвязанности, которая недавно была включена в повестку дня организации, она подчеркивает необходимость для ОБСЕ содействовать сопряжению различных интеграционных процессов в регионе ОБСЕ (развивающихся, в частности, в рамках ЕС и Евразийского экономического союза) с перспективой формирования «Большого евразийского партнерства».

В рамках Форума ОБСЕ по сотрудничеству в области безопасности Россия участвует в обсуждении военно-политических вопросов европейской безопасности, таких, в частности, как активизация военной деятельности вдоль линии соприкосновения России и НАТО. Однако Москва исходит из того, что контроль над обычными вооружениями - предмет обсуждения между Россией и НАТО, а не в рамках ОБСЕ. Для обсуждения же вопроса о модернизации Венского документа ОБСЕ о мерах укрепления доверия и безопасности, с точки зрения Москвы, необходимо, чтобы 
НАТО сначала прекратила наращивать военную деятельность на своем «восточном фланге», а затем и свернула $e^{16}$.

\section{Рекомендации}

Определение общего знаменателя и возрождение чувства общности целей государств-участников ОБСЕ потребует комплексных переговоров между Россией и Западом. Такие переговоры могут привести к прочному соглашению с Россией только в том случае, если при этом не будут обходиться стороной принципиальные для Москвы вопросы, в частности, о неделимости безопасности. В ходе переговоров не могут не затрагиваться многие сложные вопросы, включая место «человеческого измерения», а также относительно автономный статус институтов ОБСЕ. Представляется, что в настоящее время условия для принятия взаимоприемлемых решений по широкому кругу таких вопросов еще не созданы. Тем не менее, даже если сегодня согласование нового статус-кво может показаться преждевременным, это не должно препятствовать достижению договоренности о поддержании в обозримой перспективе определенного модус вивенди.

Официально заявленные позиции России не следует принимать как окончательные. Многие заявления Российской Федерации выглядят как часть риторической конфронтации в ОБСЕ. Пределы возможного компромисса, однако, могут быть выявлены только при возобновлении предметного диалога. Вот почему, несмотря на широко распространенный скептицизм, стоит рассмотреть возможность воспользоваться предстоящим 50-летием подписания хельсинкского Заключительного акта как поводом для начала диалога «Хельсинки+50». Его целью было бы согласование общего для государств-участников видения целей, стоящих перед ОБСЕ на ближайшие годы. В ходе такого диалога следовало бы продолжить обсуждение вопроса о принятии учредительного документа ОБСЕ, который поставит ее деятельность на договорную основу и позволит подписать конвенцию о правосубъектности ОБСЕ, текст которой давно согласован государствами-участниками. Учредительным документом должны быть определены, в частности, правила процедуры и рабочие методы институтов ОБСЕ. При этом, с точки зрения автора, разумным компромиссом могло бы стать сохранение существующего статус-кво, тот есть - нынешнего уровня автономии этих институтов. Определение общего знаменателя, позволяющего сочетать свободу выбора союзов с другим обязательством по документам ОБСЕ - необходимостью учитывать законные интересы безопасности соответствующих государств (или «неделимость безопасности») - еще один принципиальный вопрос, который нельзя обойти стороной в ходе диалога.

Диалог «Хельсинки+50» мог бы включать обсуждение вопросов, которые вызывают споры, но в то же время являются предметом озабоченности как России, так и Запада. В частности, ОБСЕ могла бы уточнить положения, касающиеся свобо- 
ды СМИ и доступа к информации. И Россия, и Запад считают, что сегодня они находятся в состоянии информационной войны с использованием новых цифровых технологий и социальных сетей. Поскольку свобода информации тесно связана с дискуссией о возможности вмешательства во внутренние дела государств с помощью новых информационно-коммуникационных технологий, государства-участники ОБСЕ могли бы также уточнить современное понимание принципа невмешательства.

Наконец, с российской точки зрения, ОБСЕ следовало бы расширить пространство деятельности, осуществляемой в общих интересах государств-участников, наращивая сотрудничество в сферах, не являющихся предметом споров, даже если они не затрагивают принципиальные вопросы современной дискуссии. Наиболее очевидные области, в которых это можно было бы сделать, - противодействие новым (транснациональным) угрозам и преодоление последствий пандемии коронавируса.

\section{Примечания}

1 Matveev A. The OSCE Identity Crisis // The OSCE Yearbook 1999 / IFSH (ed.). - BadenBaden: Nomos, 2000. P. 59-78.

2 Петраков М. Россия - ОБСЕ // Ежегодник ОБСЕ 2000: Ежегодник по вопросам Организации по безопасности и сотрудничеству в Европе (Институт исследования проблем мира и политики безопасности, Гамбург; МГИМО). Пер. с нем. - М.: Права человека. 2002. - С. $53-62$.

3 Alexeev A.N. The Future of the OSCE: Russia's Version // Challenges Faced by the OSCE During 2001 / D. Warner, V. Clerc (eds.). - Geneva: The Graduate Institute of International Studies, 2002. P. 151-166.

4 Костин С. Реформирование ОБСЕ - необходимое условие для дальнейшего существования организации // Право и безопасность. - 2013. - №1-2. - C. 106. URL: https://dpr.ru/ pravo/pravo_40_20.pdf. См. также: Воронков Л. ОБСЕ и европейская безопасность. Что дальше? // Современная Европа. - 2018. - №1. - C. 73. URL: https://mgimo.ru/library/publica tions/obse i_evropeyskaya_bezopasnost_chto_dalshe/.

5 Заседание Международного дискуссионного клуба «Валдай», 27 октября 2016 г. // Президент России. URL: http://kremlin.ru/events/president/news/53151.

6 Беседы автора статьи с членами группы в 2005 году.

7 О предстоящем рабочем визите в Россию Министра иностранных дел Швеции, Действующего председателя ОБСЕ А. Линде // Министерство иностранных дел Российской Федерации. 2021. 1 февраля. URL: https://www.mid.ru/ru/foreign_policy/rso/osce/-/asset_publisher/bz hxR3zkq2H5/content/id/4546081.

Выступление Министра иностранных дел Российской Федерации С.В.Лаврова на заседании Совета министров иностранных дел ОБСЕ в Тиране, 3 декабря 2020 года // Министерство иностранных дел Российской Федерации. URL: https://www.mid.ru/web/guest/foreign policy/rso/osce/-/asset_publisher/bzhxR3zkq2H5/content/id/4465649.

9 Высказывания высокопоставленного представителя МИД России в ходе российско-германского диалога в апреле 2021 года. 
10 Zagorski A. Make the OSCE institutions less dependent on politics, not more // Helsinki Monitor. - Vol. 16 (2005). - № 3. P. 209-213.

11 Выступление Министра иностранных дел Российской Федерации С.В. Лаврова на заседании Совета министров иностранных дел ОБСЕ в Тиране, 3 декабря 2020 года.

12 Выступление и ответы на вопросы СМИ Министра иностранных дел Российской Федерации С. В. Лаврова в ходе совместной пресс-конференции по итогам переговоров с Министром иностранных дел Швеции, Действующим председателем ОБСЕ А. Линде, Москва, 2 февраля 2021 года // Министерство иностранных дел Российской Федерации. URL: https:// www.mid.ru/en/web/guest/obycnye-vooruzenia/-/asset_publisher/MlJdOT56NKIk/content/id/45 50431?p_p_id=101_INSTANCE_MIJdOT56NKIk\&_101_INSTANCE_MIJdOT56NKIk_langua geId=ru_RU.

13 Если не указано иное, основано на следующих источниках: Выступление Министра иностранных дел Российской Федерации С.В. Лаврова на заседании Совета министров иностранных дел ОБСЕ в Тиране, 3 декабря 2020 года; Выступление и ответы на вопросы СМИ Министра иностранных дел Российской Федерации С.В. Лаврова в ходе совместной пресс-конференции по итогам переговоров с Министром иностранных дел Швеции, Действующим председателем ОБСЕ А. Линде, Москва, 2 февраля 2021 года; О предстоящем рабочем визите в Россию Министра иностранных дел Швеции, Действующего председателя ОБСЕ А. Линде // Министерство иностранных дел Российской Федерации. 2021. 1 февраля. URL: https://www.mid.ru/ru/foreign_policy/rso/osce/-/asset_publisher/bzhxR3zkq2H5 /content/id/4546081.

14 Выступление постоянного представителя Российской Федерации А.К. Лукашевича на онлайн-заседании Постоянного совета ОБСЕ об улучшении научно-технического сотрудничества в ответ на распространение пандемии коронавируса, Вена, 11 марта 2021 года // Министерство иностранных дел Российской Федерации. URL: https:/www.mid.ru/ru/foreign_policy/rso/osce/-/asset_publisher/bzhxR3zkq2H5/content/id/4623389.

15 Выступление постоянного представителя Российской Федерации А.К. Лукашевича на заседании Постоянного совета ОБСЕ, 15 июля 2021 года // Министерство иностранных дел Российской Федерации. URL: https://www.mid.ru/ru/foreign_policy/rso/osce/-/asset_publisher /bzhxR3zkq2H5/content/id/4814857.

16 Выступление руководителя делегации Российской Федерации на переговорах в Вене по вопросам военной безопасности и контроля над вооружениями К.Ю. Гаврилова на 967-м пленарном заседании Форума ОБСЕ по сотрудничеству в области безопасности, Вена, 3 февраля 2021 года // Министерство иностранных дел Российской Федерации. URL: https:// www.mid.ru/ru/foreign_policy/rso/osce/-/asset_publisher/bzhxR3zkq2H5/content/id/4552424. 


\title{
Франция и ОБСЕ
}

\author{
Барбара Куни
}

\section{Аннотаиия}

В статье представлен обзор роли Франции в ОБСЕ и места, которое организация занимает во внешней политике страны. В ней показано, что Франция больше всего вовлечена в первое, военно-политическое измерение ОБСЕ, в частности, в контексте урегулирования конфликтов. Третье, человеческое измерение - еще один приоритет Франции. В целом, однако, участие Франции в ОБСЕ слабо связано с ее общим стремлением играть важную роль в глобальных делах. Французские внешнеполитические деятели не считают ОБСЕ ключевым форумом, который позволит стране быстро добиться политических результатов. Хотя Париж продолжает подчеркивать приверженность многостороннему подходу в своей декларативной внешней политике, он не стремится к тому, чтобы ОБСЕ стала самостоятельным субъектом политики. По этой причине Франция выступает против увеличения финансирования организации. Учитывая давние приоритеты Франции в области внешней политики и политики безопасности маловероятно, что ее подход к ОБСЕ изменится в обозримом будущем.

\section{Введение}

Хотя Францию сначала пришлось убеждать поддержать идею созыва Совещания по безопасности и сотрудничеству в Европе (СБСЕ), позже переименованного в ОБСЕ, в итоге она стала играть важную роль в организации. Парижская Хартия была подписана в 1990 г. в столице Франции, а правительство страны добилось того, что французы занимали высшие должности в ОБСЕ. С 2005 по 2011 г. французский дипломат Марк Перрен де Бришамбо занимал пост Генерального секретаря ОБСЕ, а бывший министр Франции по европейским делам Арлем Дезир занимал пост Представителя ОБСЕ по вопросам свободы СМИ в 2017-2020 гг.

Сегодня Франция участвует в повседневной деятельности ОБСЕ. Она направляет наблюдателей во все миссии по наблюдению за выборами. Несколько десятков французских граждан работают в секретариате и других структурах организации. Участие Франции еще более заметно в деятельности по урегулированию конфликтов в регионе ОБСЕ: страна играет роль в усилиях по урегулированию как в Нагорном Карабахе, так и в конфликте в Украине и вокруг нее. Во взаимодействии

* Барбара Кунц

Институт исследований проблем мира и политики безопасности при Университете Гамбурга (IFSH),kunz@ifsh.de. 
с ОБСЕ Франция также принимала активное участие в посредничестве в ходе конфликта в Грузии в 2008 г.

В то же время, однако, Францию вряд ли можно назвать настоящей движущей силой организации. Ее деятельность в ОБСЕ не соответствует ее амбициям в отношении ее роли в Европе и в мире. ОБСЕ по-прежнему не фигурирует в дискуссиях о внешней политике Франции, несмотря на то, что целый ряд вопросов, которыми занимается ОБСЕ, относится к приоритетам внешней политики страны, начиная от большой геополитики и заканчивая более техническими вопросами. Так, ОБСЕ даже не упоминается в стратегическом обзоре (actualisation stratégique) Франции, опубликованном в феврале 2021 г. ${ }^{1}$

В статье роль Франции в ОБСЕ рассматривается в контексте более общих тенденций французской внешней политики и политики безопасности. Сначала описывается деятельность страны в ОБСЕ, а затем рассматривается роль организации в достижении целей французской внешней политики. В статье делается вывод о том, что «добавленная стоимость» ОБСЕ не всегда очевидна для Франции, что объясняет, почему страна не является движущей силой в организации и не считает ОБСЕ ключевым форумом для реализации своих внешнеполитических приоритетов.

\section{Посредничество в урегулировании затяжных конфликтов}

Первое измерение, и, в частности, урегулирование конфликтов, является ключевой сферой участия Франции в ОБСЕ. Этим вопросам в стране уделяется наибольшее внимание. Франция участвовала в попытках урегулировать два ключевых конфликта в регионе ОБСЕ: между Арменией и Азербайджаном вокруг Нагорного Карабаха и конфликт в Украине и вокруг нее. Что касается первого конфликта, Франция является сопредседателем Минской группы (вместе с США и Россией), которая работает над мирным урегулированием конфликта ${ }^{2}$. После возобновления военных действий в конце 2020 г. во Франции развернулась дискуссия по вопросу о признании Нагорного Карабаха в качестве независимого государства. Обе палаты французского парламента проголосовали за предложение консервативной партии Республиканцев (Les Républicains), которая в первую очередь была заинтересована в поддержке «восточных христиан». Это - относительно популярная тема во Франции, особенно в правой части политического спектра ${ }^{3}$. Отклонив данное предложение, правительство Франции тем самым подчеркнуло свою заинтересованность в продолжении сопредседательства в Минской группе, что было бы несовместимо с официальным признанием Нагорного Карабаха ${ }^{4}$. Франция имеет давние связи с Арменией, которая входит в состав Международной организации Франкофонии (сотрудничества франкоязычных стран мира), в силу значительного числа французских граждан армянского происхождения. Франция также официально признала факт геноцида армян. 
Возможно, еще большей международной известностью пользуется тот факт, что Франция является одним из двух «западных» членов Нормандского формата (наряду с Германией), нацеленного на урегулирование украинского конфликта. Французские президенты и официальные лица участвовали, а иногда и принимали у себя несколько встреч высокого уровня, результатом которых, в частности, стало соглашение «Минск-2» ${ }^{5}$. В контексте деятельности ОБСЕ до июня 2021 г. французский дипломат Пьер Морель возглавлял подгруппу по политическим вопросам Трехсторонней контактной группы по мирному урегулированию ситуации в Восточной Украине. Франция также вносит как финансовый, так и кадровый вклад в работу Специальной мониторинговой миссии ОБСЕ в Украине.

Помимо очевидного интереса Франции к урегулированию конфликтов, ее заметная роль в вышеупомянутых форматах также соответствует ее самовосприятию как значимого глобального актора. Будучи постоянным членом Совета Безопасности $\mathrm{OOH}$, Франция и ее дипломаты верят в необходимость играть решающую роль на международной арене и в высокопрофильной дипломатии. И Минская группа, и Нормандский формат позволяют Франции сидеть за одним столом с другими крупными державами, что делает участие в них привлекательным с точки зрения Парижа.

\section{Права человека как приоритет}

Во французском внешнеполитическом дискурсе проблематика прав человека всегда занимала важное место. Это связано с самовосприятием Франции как «страны прав человека», несущей особую ответственность, вытекающую из Декларации прав человека и гражданина 1789 г. Соответственно, помимо упомянутой выше деятельности в области первого измерения, многие французские начинания относятся к третьему (человеческому) измерению ОБСЕ. Возможно, наиболее заметной в прошедшем году была поддержка Францией задействования Московского механизма 6 после предположительно фальсифицированных президентских выборов в Беларуси в 2020 г., когда белорусский режим подавлял мирные демонстрации и нарушал права человека. Франция стала одним из семнадцати государств-участников, задействовавших Механизм по инициативе Соединенного Королевства ${ }^{7}$. Франция является также сопредседателем неформальной Группы друзей ОБСЕ по вопросам безопасности журналистов ${ }^{8}$. Одним из пунктов французской повестки дня является гендерное равенство. В частности, летом 2021 г. в Париже был проведен форум «Поколение равенства», на котором ОБСЕ обязалась «улучшить гендерное равенство путем принятия мер по вопросам гендерного насилия, экономической справедливости и прав, а также технологий и инноваций» ${ }^{9}$. Еще одним важным для Парижа вопросом является борьба с торговлей людьми ${ }^{10}$. 


\section{Скептицизм в отношении «добавленной стоимости» ОБСЕ}

Несмотря на приведенные выше примеры деятельности Франции в ОБСЕ, организация в целом не занимает важное место в повестке дня страны. В последние годы это, пожалуй, стало еще более очевидным. После избрания Эммануэля Макрона президентом Франции прагматизм стал основным элементом французской внешней политики и политики безопасности: во главу угла ставится достижение конкретных политических целей, а те или иные международные форматы и структуры оцениваются с точки зрения того, насколько они могут способствовать их достижению. Яркой иллюстрацией данного подхода стало относительное снижение значимости идеи «Европейской обороны» - общей политики безопасности и обороны $\mathrm{EC}$, учреждение и укрепление которой было давней целью французской политики. При Макроне политика страны заключалась в использовании гибких многосторонних форматов и форматов с ограниченным кругом участников, взаимодействие в которых могло дать конкретные результаты, например, в борьбе с терроризмом в Сахельском регионе - на одном из ключевых направлений французской внешней политики и политики безопасности.

Именно с учетом этого следует понимать отношение Франции к ОБСЕ. Хотя Париж постоянно подчеркивает важность многостороннего подхода и вместе с Германией даже является соучредителем «Альянса в поддержку мультилатерализма» ${ }^{11}$, на деле для французской внешней политики последних лет в значительной степени была характерна тенденция к односторонними действиям ${ }^{12}$. Для Франции тот факт, что ОБСЕ осталась единственной общеевропейской организацией, занимающейся вопросами безопасности, и многосторонней площадкой, не является достаточным основанием для инвестирования в нее. Этим страна отличается от наиболее активных государств-участников, в частности, Германии и Швейцарии. К тому же географический охват ОБСЕ не включает регионы, которые представляют наибольший интерес для Франции. До последнего времени Центральная и Восточная Европа к западу от России не занимали заметное место во французской внешнеполитической мысли. Франция традиционно больше ориентирована на Африку, Ближний Восток и во все большей степени - на Индо-Тихоокеанский регион.

Более того, в свете многочисленных проблем, с которыми сталкивается ОБСЕ, ее «добавленная стоимость» не очевидна для Парижа. Это связано как с неочевидностью той пользы, которую организация приносит в плане обеспечения европейской безопасности, так и с тем фактом, что основной причиной проблем, с которыми она сталкивается, является главный вызов в области безопасности - конфликт с Россией и ее союзниками. Париж редко рассматривает ОБСЕ как инструмент, пригодный для реализации его собственных интересов. Одна из сфер, в которых этот скептицизм проявляется наиболее явно, - позиция Франции в отношении бюджета организации. Париж считает несправедливым, что деятельность ОБСЕ финансируется главным образом странами-членами ЕС, США, Канадой, Швейцарией и Нор- 
вегией. В 2018 г. обязательные взносы Франции в сводный бюджет в размере 138 млн евро составили 14,6 млн евро (к этому следует добавить добровольные взносы, например, 7,6 млн евро в бюджет Специальной мониторинговой миссии в том же году $)^{13}$. В 2019 г. Франция на этом основании заблокировала принятие бюджета организации ${ }^{14}$. В ходе обсуждения сводного бюджета на 2020 г. Франция вновь заявила, что считает «неприемлемой ситуацию, когда финансирование 99 процентов бюджета ОБСЕ ложится на плечи всего 17 государств-участников» ${ }^{15}$. Вследствие ограниченности финансовых ресурсов для целей внешней политики страны и в общем контексте жесткой экономии после кризиса евро ${ }^{16}$ Париж решительно настаивает на принципе «нулевого номинального роста», т.е. отказа от увеличения бюджета ОБСЕ. С учетом инфляции это фактически означает сокращение бюджета организации ${ }^{17}$.

Нежелание Франции предоставить в распоряжение ОБСЕ большее финансирование также следует рассматривать на фоне ее неудовлетворенности управлением организацией. Париж признает необходимость повышения ее эффективности. В то же время он не заинтересован в том, чтобы ОБСЕ стала самостоятельным актором, реализующим собственные стратегии. Это проявилось, в частности, в скептическом отношении Франции к созданию в секретариате при Генеральном секретаре Томасе Гремингере, известном своим амбициозным подходом к повышению стратегической значимости ОБСЕ, небольшого подразделения по обеспечению стратегической политики. Франция предпочитает, чтобы ОБСЕ оставалась межправительственной организацией, ограничивая полномочия Вены и не отдавая ей на откуп «разработку стратегии». Тот факт, что Гремингер так и не был официально принят в Париже, служит еще одним наглядным примером ограниченного интереса Франции к организации.

Таким образом, общие дипломатические амбиции Франции контрастируют с ее участием в урегулировании конфликтов и повседневной деятельностью в рамках ОБСЕ. Французская дипломатия публично поддерживает ОБСЕ. Франция вносит свой вклад в деятельность организации - как финансовый, так и путем предоставления в ее распоряжение (прикомандированного) персонала. В этом смысле она является лояльной участницей, готовой сделать все необходимое для поддержания ОБСЕ на плаву. В то же время она не заинтересована в расширении той ограниченной автономии ОБСЕ в принятии решений, которую она имеет в настоящее время.

\section{Парижу не хватает «рефлекса ОБСЕ»}

Неудивительно, что Франция преследует большинство своих целей в области внешней политики и политики безопасности вне ОБСЕ, а ОБСЕ не уделяется большое внимание (если вообще уделяется) во французских политических дискуссиях. Яркой иллюстрацией этого стала президентская кампания 2017 г., в ходе которой 
несколько кандидатов, представлявших весь политический спектр, призывали к проведению общеевропейской конференции по безопасности. Но ни один из них не упомянул ОБСЕ. Президент Макрон неоднократно говорил о необходимости «пересмотреть» архитектуру европейской безопасности и возобновить диалог с Россией ${ }^{18}$. Сугубо двусторонний «стратегический диалог» Франции с Россией был начат в 2019 г. В частности, он включает встречи в формате «2+2»- министров иностранных дел и обороны двух стран. Макрон назначил Пьера Вимона, одного из самых высокопоставленных дипломатов Франции, «специальным посланником по архитектуре безопасности и доверия с Россией» ${ }^{19}$. Упоминания и ссылки на ОБСЕ отсутствуют в этой инициативе, хотя она напрямую соотносится с сутью того, чем занимается организация. Возможно, свою роль в решении не обсуждать данную инициативу в рамках ОБСЕ сыграли опасения того, что она увязнет в разногласиях внутри организации и в ее общей неспособности добиться результата, о чем свидетельствует опыт «структурированного диалога». Возможно, правда, что такая возможность просто никому не приходила в голову, что свидетельствует об отсутствии у Парижа «рефлекса ОБСЕ»: об ОБСЕ не никто не вспоминает при принятии решений о предпочтительных вариантах продвижения интересов Франции.

Помимо больших геополитических вопросов есть примеры более технических инициатив, которые, безусловно, связаны с деятельностью ОБСЕ, но не выносились на рассмотрение в организации. Так, одной из тем первого измерения, которую Франция продолжает продвигать в рамках ОБСЕ, является борьба с незаконной торговлей легким и стрелковым оружием (ЛСО). В то же время Франция выступает с параллельными инициативами в данной области вне ОБСЕ. Примером может служить франко-германская инициатива по борьбе с незаконной торговлей ЛСО на Западных Балканах ${ }^{20}$. Несмотря на то, что ОБСЕ осуществляет деятельность по ЛСО, франко-германская инициатива обсуждалась лишь на параллельном мероприятии во время проведения встречи Совета министров 2018 г. в Милане 21.

Франция не является движущей силой крупных инициатив в рамках ОБСЕ. Генераторами таких инициатив, как правило, являются Германия и Швейцария. Нередко Франция поддерживает их, как в 2016 г., когда Германия инициировала «структурированный диалог» с целью возродить контроль над обычными вооружениями в Европе. Франция - одна из многих стран-единомышленников, призывающих к возобновлению переговоров на эту тему, на что была нацелена инициатива Штайнмайера ${ }^{22}$.

\section{Перспективы на будущее: изменения кажутся маловероятными}

Франция неохотно использует свой дипломатический вес в рамках ОБСЕ. За исключением отдельных вопросов, таких как Украина, роль Франции в организации редко соответствует ее самовосприятию как глобальной державы, являющейся постоян- 
ным членом Совета Безопасности ООН. В некотором смысле отношения между Францией и ОБСЕ можно охарактеризовать как череду упущенных возможностей. Так, достойно сожаления, что не было должным образом отмечено 30-летие парижской Хартии. Это можно списать на то, что летом 2020 г. организация оказалась без руководства, а также на пандемию. Однако юбилей парижской Хартии стал бы прекрасным поводом для того, чтобы подчеркнуть важность поддержания основанного на правилах европейского порядка безопасности. Тот факт, что Генеральный секретарь ОБСЕ Томас Гремингер так и не был принят министром иностранных дел Франции, можно объяснить только отсутствием интереса. Обнадеживает, что в июле 2021 г. в Париже состоялась встреча преемницы Гремингера, немецкого дипломата Хельги Шмид с государственным министром Франции по европейским делам Клеманом Бо́ном и министром иностранных дел Жан-Ивом Ле Дрианом ${ }^{23}$.

Деятельность Франции в ОБСЕ вряд ли будет меняться в средне- и долгосрочной перспективе. Главная причина заключается в том, что организация не имеет большого значения с точки зрения основных внешнеполитических целей и ключевых вызовов, которые Франция определила для себя и для Европы. В документе 2021 г. «Стратегическое обновление» акцентируется внимание на джихадистском терроризме, распространении оружия массового уничтожения и «возобновлении стратегического соперничества между великими державами» ${ }^{24}$, причем последний тезис относится прежде всего к отношениям между Соединенными Штатами и Китаем. В целом Франция явно ожидает ускорения деградации стратегической обстановки в Европе. Это, вероятно, заставит будущих президентов и правительства Франции еще больше сосредоточить внимание на приоритетных направлениях политики с точки зрения как финансирования и кадрового обеспечения, так и выбора дипломатических каналов, которые представляются Парижу наиболее перспективными для укрепления европейской безопасности и продвижения французских и европейских интересов. ОБСЕ, как правило, не занимается приоритетными для Франции вопросам ни функционально, ни географически. Поэтому ожидать значительных изменений в позиции Франции по отношению к ОБСЕ нереалистично.

\section{Примечания}

1 CM.: Actualisation stratégique // French Ministry of the Armed Forces, February 2021. URL: https://www.defense.gouv.fr/dgris/presentation/evenements/actualisation-strategique-2021. Официальный перевод на английский язык доступен по той же ссылке.

2 Отметим, что Минская группа не является институтом ОБСЕ в строгом смысле, хотя и имеет тесные связи с организацией. Три сопредседателя Минской группы не сыграли заметной роли в урегулировании карабахской войны 2020 г. Все более сложные отношения Франции с Турцией, включая опасные инциденты с участием военных кораблей в Восточном Средиземноморье в июне 2020 г., а также личные нападки на Эммануэля 
Макрона со стороны президента Эрдогана, по всей видимости, до сих пор не повлияли на роль Франции в Минской группе.

3 См., в частности: Rich D. La cause des chrétiens d'Orient suscite de vives oppositions politiques en France// France24. 2021. 5 March. URL: https://www.france24.com/fr/moyen -orient/20210305-d\%C3\%A9fense-des-chr\%C3\%A9tiens-d-orient-la-cause-suscite-de-vives-opp ositions-politiques-en-france.

4 См.: Senneville F. Pourquoi la France ne veut-elle pas reconnaître le Haut-Karabakh? // LCI. 2020. 4 December. URL: www.lci.fr/international/pourquoi-la-france-ne-veut-pas-reconnaitrele-haut-karabakh-2171958.html.

5 Подробнее см.: At a Glance: Ukraine: The Minsk agreement five years on. European Parliamentary Research Service, March 2020. URL: https://www.europarl.europa.eu/RegData/etudes/ ATAG/2020/646203/EPRS_ATA(2020)646203_EN.pdf.

6 См.: Московский механизм // Официальный сайт ОББСЕ. URL: https://www.osce.org/files/f/ documents/b/3/20067.pdf.

7 См.: Liechtenstein S. Exclusive: Austrian professor nominated for OSCE mission to investigate human rights violations in Belarus // Security and Human Rights Monitor. 2020. 23 September. URL: https://www.shrmonitor.org/exclusive-nomination-austrian-professor-for-osce-mission-to -investigate-human-rights-violations-in-belarus/.

8 См.: Твиттер французского представительства в ОБСE. URL: https://twitter.com/RP_France OSCE/status/1394670737051504640/photo/1.

9 OSCE commits to new gender equality targets at Generation Equality Forum in Paris. OSCE. Press Release. 1 July 2021 // Официальный сайт ОБCE. URL: https://www.osce.org/secretariat /491506.

10 См.: OSCE Special Representative commends France on prioritizing fight against trafficking and calls for strengthening victim-centred approaches. OSCE. Press Release. 2 July $2021 / /$ Официальный сайт ОБСЕ. URL: https://www.osce.org/cthb/491620.

11 Более подробную информацию можно найти на веб-сайте Альянса: https:/multilateralism.o $\mathrm{rg} /$.

12 CM.: Kempin R. (ed.). France's foreign and security policy under President Macron. SWP Research Paper. 2021. 4. May. URL: https://www.swp-berlin.org/en/publication/frances-foreign -and-security-policy-under-president-macron/.

13 См.: Франция и ОБСЕ // Официальный сайт Министерства иностранных дел Франции. 2020. Декабрь. URL: https://www.diplomatie.gouv.fr/ru/politique-etrangere/securite-desarmem ent-et-non-proliferation/la-france-et-l-osce/.

14 См.: Gauquelin B. La France bloque le budget 2019 de l'OSCE // Le Monde. 2019. 8 January. URL: https://www.lemonde.fr/international/article/2019/01/08/la-france-bloque-le-budget-2019 -de-l-osce 5406338_3210.html.

15 Решение № 1369. Утверждение сводного бюджета на 2020 год. 1269-е пленарное заседание. PC Journal No 1269. Пункт 6 повестки дня. 28 мая 2020. С. 83 // Официальный сайт ОБСЕ. URL: https://www.osce.org/files/f/documents/4/7/454897.pdf.

16 В последние годы бюджет министерства иностранных дел Франции был значительно урезан. С 2007 по 2020 г. оно потеряло около 10\% своего персонала из-за бюджетных ограничений, а его финансирование ежегодно сокращалось вплоть до пандемии. См.: France cuts billions from public spending to meet EU limit // BBC. 2017. 11 July. URL: https:// www.bbc.com/news/world-europe-40569589.

17 См.: Simonet L. Twenty Years after the Istanbul Platform for Co-operative Security: How Can the OSCE's Contribution to 'Effective Multilateralism' Be Strengthened through Co-operation with Other International and Regional Organizations? // OSCE Yearbook 2019 / IFSH (ed.). Baden-Baden: Nomos, 2020. Pp. 249-272. URL: https://ifsh.de/file/publication/OSCE_Yearbook _en/2019/Simonet.pdf. 
18 Наиболее заметными были выступления президента Макрона на ежегодных конференциях послов в августе 2018 и 2019 гг. См.: Discours du Président de la République à la conférence des Ambassadeurs // Présidence de la République. 2018. 27 Août. URL: https://w ww.elysee.fr/emmanuel-macron/2018/08/27/discours-du-president-de-la-republique-a-la-confere nce-des-ambassadeurs; Discours du Président de la République à la conférence des ambassadeur s // Présidence de la République. 2019. 27 Août. URL: https://www.elysee.fr/emmanuel-macron/ 2019/08/27/discours-du-president-de-la-republique-a-la-conference-des-ambassadeurs-1.

19 Подробнее см: Liechtenstein S. If we want to defend Europe's interests, we have to engage with Russia (interview with Pierre Vimont) // Security and Human Rights Monitor. 2021. 14 April. URL: https://www.shrmonitor.org/if-we-want-to-defend-europes-interests-we-have-to-engage-w ith-russia-dialogue-with-russia/.

20 См.: Франко-германская инициатива по борьбе с незаконной торговлей огнестрельным оружием на Западных Балканах // Официальный сайт Министерства иностранных дел Франции. 2020. 30 января. URL: https://www.diplomatie.gouv.fr/ru/politique-etrangere/securit e-desarmement-et-non-proliferation/desarmement-et-non-proliferation/article/initiative-franco-al lemande-sur-la-lutte-contre-les-trafics-illicites-d-armes-a.

21 См.: Franco-German roadmap for comprehensive control of small arms and light weapons discussed in side event at OSCE Ministerial Council in Milan // Официальный сайт ОБСЕ. 2018. 7 December 2018. URL: https://www.osce.org/chairmanship/405647.

22 См.: Relaunching conventional arms control in Europe // German Federal Foreign Office. 2016. 25 November. URL: https://www.auswaertiges-amt.de/en/aussenpolitik/themen/abruestung/1611 25-ruestungskontrolle/285652.

23 См.: Твиттер Генерального секретаря Хельги Шмид. URL: https://witter.com/HelgaSchmid SG/status/1410630567222202373?s=20.

24 Actualisation stratégique. Р. 14 (английская версия). 


\title{
Турция и ОБСЕ
}

\author{
Гирай Сadbıк*
}

\section{Аннотация}

В статье представлены отношение Турции к ОБСЕ и связываемые с ней ожидания. Рассматриваются место организации во внешней политике и политике безопасности Турции, слабые места в деятельности ОБСЕ, как они видятся в Турции, и приоритеты правительства страны во взаимодействии с организацией. Основной интерес Турции в том, что касается ОБСЕ, заключается в повышении эффективности ее деятельности по стабилизации положения в зоне кризисов в ближайшем окружении страны. Другие приоритеты Турции - борьба с терроризмом и транснациональной организованной преступностью.

\section{Введение}

Турция занимает уникальное геостратегическое положение в регионе ОБСЕ. Она граничит с Балканами, Черным морем, Кавказом, Ближним Востоком и Средиземноморьем. В настоящей статье представлены отношение Турции к ОБСЕ и связываемые с ней ожидания. В ней сначала рассматривается место организации во внешней политике и политике безопасности страны. Затем обсуждаются слабые места в деятельности ОБСЕ, как они видятся в Турции, анализируются приоритеты правительства страны во взаимодействии с организацией. В заключении сформулированы рекомендации относительно будущей деятельности ОБСЕ в свете подходов властей Турции.

\section{Место ОБСЕ во внешней политике и политике безопасности Турции}

Турция с самого начала была вовлечена в процесс СБСЕ-ОБСЕ и остается его активной участницей. Она поддерживает повышение роли ОБСЕ, особенно в своем непосредственном соседстве, где она сталкивается с проблемами управления потоками нелегальной миграции и урегулирования региональных конфликтов, таких как конфликты в Сирии и Ливии, имеющими долгосрочные последствия для Восточного Средиземноморья. Такие вызовы приобретают все более гибридный характер,

* Гирай Садык

Университет им. Йылдырыма Беязита, Анкара, gsadik@ybu.edu.tr. 
а границы между национальной и международной, гражданской и военной, физической и кибербезопасностью становятся все более размытыми.

Турция вступила в НАТО и Совет Европы в первые годы «холодной войны». Эти организации обеспечивали и, очевидно, и в дальнейшем будут обеспечивать тесную связь страны с Западом. В контексте своей политики эффективного мультилатерализма Турция поддерживает синергию и взаимодополняемость между этими западными политической и военной организациями и ОБСЕ.

Турция считает, что между ОБСЕ и Советом Европы существуют особые отношения и что они работают в тандеме. Бывший постоянный представитель Турции при ОБСЕ посол Рауф Энгин Сойсал так подчеркивает преимущества тесного сотрудничества между ними: «Международные организации, осуществляющие деятельность в одной и той же области, - под „областью” в данном случае я понимаю как географическую, так и тематическую сферу деятельности - не обречены на конкуренцию. Напротив, положительные эффекты пересечения в их деятельности и взаимовлияния могут взаимно подкреплять результаты их работы. Поэтому мы высоко оцениваем усилия по укреплению диалога и институционального сотрудничества между ОБСЕ и Советом Европы. Синергия на исполнительном и техническом уровнях двух организаций может повысить эффективность мультилатерализма» ${ }^{1}$.

Особое внимание уделяется обеспечению синергетического эффекта от деятельности по борьбе с терроризмом и торговлей людьми. Турция придает большое значение содействию, оказываемому ОБСЕ в выполнении Дополнительного протокола к Конвенции Совета Европы о предупреждении терроризма - первого международного договора, в который были включены положения, касающиеся иностранных боевиков-террористов. Турция ратифицировала Дополнительный протокол. Он вступил в силу для нее 1 июня 2018 года²

Отношения с ЕС также являются важной, хотя и не беспроблемной частью связей Турции с Западом. ОБСЕ является для нее площадкой для поддержания диалога с EC: Турция с самого начала была в числе государств-участников организации в то время как перспектива ее вступления в ЕС остается неопределенной. В то же время, эта неопределенность пагубно влияет на многостороннее сотрудничество Турции в рамках ОБСЕ, поскольку нельзя исключать опасность того, что какое-либо государство ЕС перенесет обсуждение того или иного критически важного для Турции вопроса на площадку ЕС, на которой страна не представлена.

\section{Ожидания, связываемые Турцией с ОБСЕ}

Турция считает, что соблюдение основополагающих принципов ОБСЕ, особенно утверждение тесной взаимосвязи между безопасностью и сотрудничеством, а также лежащего в основе ее работы правила консенсуса имеют ключевое значение для 
того, чтобы ОБСЕ была сильной организацией и вносила свой вклад в обеспечение безопасности государств-участников.

Поддержка Турцией деятельности ОБСЕ по урегулированию затяжных конфликтов и ее председательство в Форуме по сотрудничеству в области безопасности (ФСОБ) в 2020 году свидетельствуют о готовности страны вносить свой вклад в усилия ОБСЕ по укреплению безопасности и стабильности в ее первом, военнополитическом измерении ${ }^{3}$. Турция подчеркивает необходимость повышения роли ФСОБ как уникальной площадки для сотрудничества и укрепления доверия.

Противодействие терроризму и другим формам трансграничной преступности, которые по-прежнему представляют собой угрозу в регионе ОБСЕ и соседних с ним регионах, было важным тематическим направлением для Турции. Она подчеркивала необходимость «одинаковой и все более решительной коллективной борьбы не только с Исламским государством, но и с другими террористическими организациями без каких-либо различий» ${ }^{4}$. Турция считает, что одинаковое и недискриминационное применение стандартов ОБСЕ в борьбе с терроризмом и другими угрозами от трансграничной организованной преступности до ксенофобии и исламофобии является важнейшим аспектом неделимости безопасности в регионе ОБСЕ.

Турция все больше обеспокоена деятельностью ОБСЕ в соседних со страной регионах и потенциальным влиянием этой деятельности на безопасность. С точки зрения Турции, государства-участники должны подавать пример, когда речь идет о наделении ОБСЕ полномочиями по урегулированию конфликтов в регионе. Турция участвует в совместном российско-турецком мониторинге прекращения огня в зоне конфликта вокруг Нагорного Карабаха и поддерживает деятельность Азербайджана по разминированию этого района.

Турция считает важным углубление отношений со средиземноморскими и азиатскими государствами-партнерами ОБСЕ и дальнейшее изучение потенциальных новых областей для сотрудничества. Сближение Турции со средиземноморскими партнерами, особенно недавние дипломатические инициативы в отношении Египта и Туниса, можно объяснить стремлением страны заручиться поддержкой в регионе на фоне кризисов в Ливии и Восточном Средиземноморье. Что касается азиатских партнеров, то здесь усилия Турции в большей мере направлены на экономическое сотрудничество с развитыми странами региона, такими как Япония, Корея и Австралия.

В том, что касается безопасности человека, Турция считает, что Бюро по демократическим институтам и правам человека (БДИПЧ) следует активнее работать в таких областях, как информирование о преступлениях на почве ненависти и интеграция мигрантов ${ }^{5}$. Анкара полагает, что ОБСЕ должна подать пример другим форумам в привлечении внимания к угрозе разжигания ненависти и расовой и религиозной дискриминации. Она подчеркивает важность достижения конкретных результатов в области толерантности и недискриминации по отношению к мусульманам. 


\section{Слабые места в деятельности ОБСЕ с точки зрения Турции}

Недовольство в Турции вызывает прежде всего применение ОБСЕ, с точки зрения Анкары, двойных стандартов, особенно в том, что касается противодействия популизму и ксенофобии. Хотя согласно Конституции Турция является светским государством, ее население преимущественно исповедует ислам, и во многих европейских государствах-участниках ОБСЕ проживает значительная по численности турецкая диаспора, самая многочисленная - в Германии. Усиливающиеся исламофобия и расизм, а также всплеск нападок на турок сделали вопрос борьбы с правым экстремизмом в Европе предметом непосредственной озабоченности Турции ${ }^{6}$. Страна ожидает всестороннего сотрудничества со стороны ОБСЕ и ее государств-участников в предотвращении таких нападок и уголовном преследовании виновных. Однако сотрудничество в данной области в лучшем случае остается крайне ограниченным, и это, вероятно, еще больше осложнит отношения Турции с организацией.

Затяжные конфликты представляют собой еще один вызов для обеспечения стабильности в регионе ОБСЕ. «Замораживание» таких конфликтов не может считаться успехом. Турция считает, что ОБСЕ должна предпринимать более активные усилия по их урегулированию, максимально используя свои широкие возможности, инструменты и потенциал ${ }^{7}$. Недовольство Турции в первую очередь вызывает неспособность Минской группы ОБСЕ положить конец конфликту в Нагорном Карабахе и широкому использованию в этом регионе запрещенных противопехотных мин.

Наконец, правительство страны скептически относится к сотрудничеству неправительственных организаций (НПО) с ОБСЕ. Участие некоторых турецких НПО в мероприятиях ОБСЕ в последние годы неоднократно становилось предметом споров между Турцией и организацией. Турецкое государство обеспокоено тем, что некоторые НПО, утверждающие, что они представляют гражданское общество, связаны с террористическими организациями. Турция настаивает на том, что ОБСЕ не должна предоставлять трибуну организациям, связанным с террористической деятельностью. Соответственно, страна ожидает, что будут полностью выполняться все положения Хельсинкского документа 1992 года о создании возможностей для более активного участия неправительственных организаций в деятельности ОБСЕ, особенно пункт, исключающий применение этих положений к лицам или организациям, которые открыто поощряют терроризм или применение насилия 8 .

\section{Перспективы}

Основной интерес Турции в сотрудничестве с ОБСЕ и другими международными организациями - обеспечение ее национальной безопасности. Латентные и активные конфликты в регионе, в котором расположена страна, - от Восточного Среди- 
земноморья до Ближнего Востока и Кавказа - делают приоритетной задачу достижения региональной стабильности.

Турция считает, что ОБСЕ и в будущем должна играть ключевую роль в поддержании основ архитектуры европейской безопасности. Чтобы вернуть себе стратегическую значимость, ОБСЕ должна своевременно реагировать на события в этой области. Поддержка таких инициатив, как создание в Агдамском районе Азербайджана турецко-российского центра по мониторингу за соблюдением режима прекращения огня в Нагорном Карабахе, может проложить путь к возобновлению взаимодействия.

Есть и другие меры, с помощью которых государства-участники, включая Турцию, могли бы способствовать повышению роли ОБСЕ. Во-первых, им следует сохранить роль организации как предпочтительной площадки для ведения переговоров и осуществления деятельности по урегулированию конфликтов там, где это возможно. Учитывая то обстоятельство, что Турция все еще только страна-кандидат на вступление в ЕС, ОБСЕ как организация с открытым составом участников имеет больше, чем ЕС, возможностей для посредничества в спорах между членами ЕС и Турцией, и поэтому можно ожидать, что она будет занимать более нейтральную позицию.

Во-вторых, необходим прагматичный подход к вопросу о взаимосвязи трех измерений ОБСЕ. Возможно, следовало бы в определенной мере отделить обсуждение одних вопросов от других. Как отметила канцлер Германии Меркель, «несмотря на серьезные разногласия по вопросу о правах человека следует поддерживать стратегические связи с Турцией» ${ }^{9}$. В последнее время ЕС руководствовался аналогичным подходом в отношениях с Венгрией и Польшей.

Как одно из государств-основателей ОБСЕ Турция также должна расширить свое участие в деятельности организации в рамках ее второго и третьего измерений. Для этого следует поощрять турецкие научные круги и гражданское общество к участию в обсуждении стоящих в повестке дня ОБСЕ вопросов на национальном и международном уровнях. Это позволило бы решить две основные задачи. Во-первых, активизировать до сих пор ограниченное взаимодействие гражданского общества и академических кругов страны с ОБСЕ и таким образом содействовать продвижению турецких подходов на международном уровне. Во-вторых, деятельность гражданского общества и научных кругов могла бы способствовать формированию во внешней политике Турции более широкого подхода к вопросу о том, какими проблемами следует заниматься ОБСЕ. Перед лицом вызовов для безопасности, с которыми сталкиваются сегодня государства и их граждане, научные круги и гражданское общество способны стать новыми силами, которые будут влиять на формирование повестки дня организации, особенно в областях, связанных с «человеческим измерением». 


\section{Примечания}

1 Statement by Ambassador Rauf Engin Soysal, Permanent Representative of Turkey, in response to H.E. Marija Pejčinović Burić, Deputy Prime Minister and Minister of Foreign and European Affairs of Croatia and Chair of the Committee of Ministers of the Council of Europe. 1189 Meeting of the Permanent Council, 14 June 2018.

2 Ibid.

3 Statement by Ambassador Rauf Engin Soysal, Permanent Representative of Turkey, in Response to Mr. George Tsereteli, President of the OSCE PA. $1255^{\text {th }}$ Meeting of the Permanent Council, 16 January 2020.

4 Statement by Ambassador Rauf Engin Soysal, Permanent Representative of Turkey, in response to the Minister of Foreign and European Affairs of Slovakia, H.E. Miroslav Lajčák. 1211 ${ }^{\text {th }}$ Special Meeting of the Permanent Council, 10 January 2019.

5 Statement by Ambassador Rauf Engin Soysal, Permanent Representative of Turkey, in Response to the Secretary General's Presentation of the 2021 OSCE Programme Outline, $1266^{\text {th }}$ Meeting of the Permanent Council, 7 May 2020.

6 Statement by Ambassador Rauf Engin Soysal, Permanent Representative of Turkey, in Response to Mr. George Tsereteli, President of the OSCE PA.

$7 \quad$ Ibid.

8 «Государства-участники будут создавать возможности для более активного участия неправительственных организаций в деятельности СБСЕ». Однако «приведенные выше положения» об увеличении транспарентности деятельности ОБСЕ, содействии пониманию деятельности СБСЕ и усилении роли НПО «не будут применяться к тем лицам или организациям, которые применяют насилие, а также открыто поощряют терроризм и применяют насилие». СБСЕ, Хельсинский документ 1992 года. Вызов времени перемен. 10 июля 1992. С. 33-34 // Официальный сайт ОБСЕ. URL: https://www.osce.org/files/f/docu ments/8/0/39534.pdf.

9 Merkel says strategic ties with Turkey should be maintained despite 'serious differences on human rights' // Duvar-English. 2021. 24 June. URL: https://www.duvarenglish.com/merkel-says -strategic-ties-with-turkey-should-be-maintained-despite-serious-differences-on-human-rights-ne ws-57944. 


\title{
Казахстан и ОБСЕ
}

\author{
Рустам Бурнамев и Ирина Черных
}

\begin{abstract}
Аннотаичя
С момента вступления Казахстана в ОБСЕ в 1992 году его отношение к организации существенно изменилось: полное принятие ее основных принципов сменилось отходом от них, особенно в том, что касается вопросов человеческого измерения. В статье рассматривается, насколько значима организация для Казахстана в настоящее время, какие ожидания он связывает с ОБСЕ и какая ее деятельность подвергается в Казахстане критике. В ней показано, что Казахстан, позиционируя сотрудничество с ОБСЕ как один из своих внешнеполитических приоритетов, воспринимает организацию не как ключевую структуру, а как одну из многих европейских и евразийских организаций, в работе которых он не участвует активно и которые, таким образом, остаются «внешними» по отношению к нему. Хотя вопросы, связанные с участием в ОБСЕ и ее развитием, находятся в поле политического дискурса Казахстана, внимание к ней в стране носит ситуативный характер. В то же время дипломатия Казахстана пользуется возможностями организации для повышения международного авторитета страны, акцентируя внимание на успехах своего председательства в ОБСЕ в 2010 г. и лоббируя создание в Нур-Султане тематического центра ОБСЕ по устойчивой взаимосвязанности.
\end{abstract}

\section{Введение}

Казахстан стал участником СБСЕ (с 1995 года - ОБСЕ) в 1992 г. после распада Советского Союза. С тех пор его отношение к организации существенно изменилось. В 1990-е годы Казахстан стремился следовать основополагающим принципам СБСЕ-ОБСЕ, прежде всего пониманию того, что «безопасность больше не основывается на балансе взаимных угроз, а опирается на установление взаимного доверия через открытость и прозрачность» ${ }^{1}$. Но к началу 2000-х гг. Казахстан все больше дистанцировался от принципов ОБСЕ, особенно в том, что касается человеческого измерения. Отчасти это было связано с резким снижением уровня доверия и сотрудничества между «западными» и «восточными» государствами-участниками ОБСЕ в конце 1990-х гг., а также с усилением авторитаризма в Казахстане и других пост-

* Рустам Бурнашев

Казахстанско-немецкий университет, Алматы, burnashev@hotmail.com.

Ирина Черных

Казахстанско-немецкий университет, Алматы, chernykhi@yahoo.com. 
советских государствах. Примерно в это же время Казахстан начал продвигать идею своего председательства в ОБСЕ. Подготовка почвы для решения этой задачи была главной целью выдвижения программы «Путь в Европу», реализация которой должна была вывести отношения Казахстана с ведущими европейскими государствами на «уровень стратегического партнерства» ${ }^{2}$. Председательство Казахстана в ОБСЕ в 2010 г. и состоявшийся в Астане саммит не вывели организацию из кризиса, не изменили характер политического режима в Казахстане и его отношение к принципам ОБСЕ. Для Казахстана и председательство, и саммит были важны не столько с содержательной точки зрения, сколько как средство для повышения международного авторитета страны. Последующие годы были отмечены относительным снижением активности как участия Казахстана в работе ОБСЕ, так и деятельности последней в стране.

\section{ОБСЕ во внешней политике и политике безопасности Казахстана}

Усиление взаимодействия в области международной безопасности в рамках ОБСЕ определяется как одно из основных направлений политики безопасности Казахстана $^{3}$. Казахстан также связывает с ОБСЕ развитие «зеленой» экономики, обеспечение энергетической безопасности, предотвращение стихийных бедствий и продвижение концепции устойчивой взаимосвязанности ${ }^{4}$. Ссылки на ОБСЕ содержатся в ряде программных документов, принятых в Казахстане. Так, в Комплексном плане по реализации государственной политики в религиозной сфере на 2021-2023 годы указывается, что «законодательство страны соответствует базовым принципам, лежащим в основе международных стандартов, принятых ОБСЕ» ${ }^{5}$. Казахстан на ежегодной основе продлевает действие мандата Программного офиса ОБСЕ в Нур-Султане, подчеркивая важность его работы во всех трех измерениях безопасности, принятых в организации ${ }^{6}$.

При этом ОБСЕ рассматривается не более чем одна из целого ряда европейских и евразийских организаций. Зачастую в официальном дискурсе речь идет не об участии Казахстана «в» ОБСЕ, а о сотрудничестве «с» ОБСЕ. Так в Концепции внешней политики Республики Казахстан на 2020-2030 годы ОБСЕ упоминается только один раз в качестве одного из приоритетов региональной и многосторонней дипломатии наряду с Организацией Договора о коллективной безопасности, Советом Европы и НАТО 7 . Таким образом, ОБСЕ позиционируется как «внешняя» организация. Казахстан, по-видимому, не принимает ее принципы и ценности как свои собственные ориентиры, а считает их навязываемыми извне.

На правительственном или парламентском уровнях не ведутся систематические обсуждения значения ОБСЕ для Казахстана и путей ее более эффективного использования. Внимание к ОБСЕ в Казахстане носит ситуативный характер и связано прежде всего с деятельностью организации, например, в связи с наблюдением за 
состоявшимися в стране в январе 2021 г. парламентскими выборами, которые были оценены как недостаточно конкурентные и имеющие системные ограничения, или в связи с визитом в Казахстан в апреле 2021 г. действующего Председателя ОБСЕ Анн Линде.

В то же время Казахстан склонен использовать ОБСЕ в рамках своей дипломатии, направленной на то, чтобы подчеркивать особую роль Нур-Султана ${ }^{8}$ Он попрежнему акцентирует значимость своего председательствования в ОБСЕ в 2010 г., подчеркивая, что Казахстан «первым среди стран СНГ [Содружества Независимых Государств] и первым среди стран Азии, мусульманского и тюркоязычного мира» возглавил организацию9 . Аналогичным образом он рассматривает назначение казахстанского дипломата Кайрата Абдрахманова на должность Верховного комиссара ОБСЕ по делам национальных меньшинств в 2020 г. ${ }^{10}$

\section{Ожидания, связываемые с ОБСЕ}

Если не считать самые общие пожелания о необходимости возрождения «духа Хельсинки» и повышения эффективности ОБСЕ, Казахстан, как правило, не формулирует какие-либо конкретные ожидания и предложения относительно деятельности организации. Тем не менее, анализ официальных документов и выступлений позволяет выделить ряд взаимосвязанных, областей, представляющих для страны особый интерес.

Во-первых, в плане региональной безопасности Казахстан считает важным, чтобы организация активизировала свои усилия по урегулированию затяжных конфликтов в регионе ОБСЕ, а также по содействию стабилизации ситуации в Афганистане. Правительство считает, что Казахстан может внести свой вклад в эти усилия, опираясь на опыт посредничества во время вспышки вооруженного насилия в соседнем Кыргызстане в период председательства Казахстана в 2010 г. и в качестве принимающей стороны астанинского процесса по урегулированию ситуации в Сирии.

Во-вторых, Казахстан считает, что катализатором снижения напряженности и укрепления доверия между государствами-участниками ОБСЕ может стать второе, экономико-экологическое измерение деятельности организации ${ }^{11}$. В частности, Казахстан ожидает, что ОБСЕ поддержит развитие транспортных коридоров, соединяющих Азию и Европу 12 .

В-третьих, Казахстан поддерживает региональные и субрегиональные проекты в Центральной Азии ${ }^{13}$, считая целесообразным добиться синергетического эффекта от деятельности полевых миссий ОБСЕ в странах Центральной Азии в таких сферах, как борьба с терроризмом, противодействие коррупции, управление границами и водными ресурсами, а также развитие цифровизации, зеленой экономики, надлежащего управления и охраны окружающей среды. Казахстан поддерживает такие 
региональные проекты, как Академия ОБСЕ в Бишкеке и Пограничный колледж ОБСЕ для руководящего состава в Душанбе ${ }^{14}$.

В-четвертых, Казахстан, использует площадку ОБСЕ для повышения своего международного авторитета. Так, в рамках инициативы «Три диалога» он предложил активизировать сотрудничество ОБСЕ с Совещанием по взаимодействию и мерам доверия в Азии ${ }^{15}$. Кампанию Казахстана по созданию в его столице тематического или регионального центра ОБСЕ по устойчивой взаимосвязанности - с такой инициативой, вызвавшей много споров среди государств-участников, страна выступила в 2017 г. - также можно рассматривать как попытку укрепить международный авторитет Казахстана ${ }^{16}$. При этом Казахстан исходит из важности равномерного распределения штаб-квартир структур организации в регионе ОБСЕ, полагая, что это будет способствовать укреплению доверия и взаимопонимания ${ }^{17}$.

Инициативы страны имеют разный уровень конкретности и практической реализуемости. Если идея развития транспортных коридоров, соединяющих Азию и Европу, и предложение об активизации региональной и субрегиональной деятельности ОБСЕ носят практический характер и могут быть реализованы, то предложения об активизации работы ОБСЕ по урегулированию конфликтов и продвижении через ОБСЕ глобальных инициатив по развитию диалога, очевидно, менее реалистичны и носят декларативный характер. Преувеличены также утверждения Казахстана о значимости и успешности его опыта посредничества в конфликтах.

Отдельные политические деятели Казахстана также выступают с предложениями относительно деятельности ОБСЕ. Так, бывший в 2010 году действующим Председателем ОБСЕ Канат Саудабаев считает, что актуальными направлениями деятельности ОБСЕ являются консолидация усилий в борьбе с COVID-19, противодействие кибератакам, а также созыв нового саммита ${ }^{18}$. Однако эти идеи не являются официальными, хотя и вписываются в общую риторику Казахстана.

\section{Отношение к проблемам, с которыми сталкивается ОБСЕ}

В настоящее время Казахстан не выступает с прямой официальной и систематической критикой в адрес ОБСЕ, за исключением общих замечаний по поводу ослабления «духа» Хельсинки и Астаны, утраты взаимного доверия и пространства для диалога, а также эскалации напряженности ${ }^{19}$. Если Казахстан и критикует ОБСЕ, то, как правило, в ответ на критические оценки со стороны тех или иных структур организации, касающиеся прежде всего соблюдения в стране прав человека и основных свобод, а также демократических процедур.

В 2010 году президент Назарбаев опубликовал статью о ключевых проблемах, стоящих перед ОБСЕ ${ }^{20}$. К ним относились: неравенство государств-участников в выработке решений проблем, которые одинаково важны для всех; нарушение военно-политического баланса на пространстве ОБСЕ; наличие «замороженных кон- 
фликтов»; фрагментация этого пространства на три зоны (Северная Америка, Европа и Азия) и недостаточная интеграция евразийского пространства в программы организации по укреплению потенциала; нарастание межнациональной и межрелигиозной напряженности; проблемы нелегальной миграции и интеграции мигрантов в общество страны пребывания.

Оснований считать, что Казахстан изменил свои оценки по указанным вопросам, нет. Время от времени официальные лица Казахстана и сейчас возвращаются к ним в своих выступлениях и заявлениях. В то же время Казахстан продолжает придерживаться положения, согласно которому «базовая деятельность ОБСЕ основывается на уже сформировавшихся принципах, стандартах и правилах, от которых Казахстан не намерен отказываться, поскольку они воплощают дух организации» ${ }^{21}$.

\section{ОБСЕ в представлении гражданского общества и академического сообщества}

Широкая систематическая дискуссия в гражданском обществе и академическом сообществе по вопросам ОБСЕ в Казахстане не ведется. Экспертные оценки ОБСЕ, как правило, можно найти только в специализированных исследованиях, например, таких как исследование Сети аналитических центров и академических институтов ОБСЕ «Центральноазиатские нарративы об ОБСЕ» 22 . Мнения об ОБСЕ широко варьируются, и не существует четко определенной общей точки зрения.

Большинство представителей экспертного сообщества, близкого к правительственным кругам, соглашается с тем, что деятельность ОБСЕ важна, но ее проекты должны быть больше ориентированы на такую деятельность, как поддержка правоохранительных органов или пограничной службы. Представители независимого академического сообщества и гражданского общества считают, что ОБСЕ мало занимается вопросами прав человека и что большинство ее проектов и программ в этой области носят декларативный характер и лишены реального содержания.

Представители академического сообщества критично оценивают проекты ОБСЕ в Казахстане, отмечая, что они ограничены в масштабах и формах их реализации по причине чрезмерной формализация деятельности организации. Они отмечают, что темы, повестка дня и участники проектов и мероприятий проходят многоступенчатый процесс согласования между официальными структурами Казахстана и организации и внутри них, что приводит к потере критического содержания и актуальности. Экспертами указывается, что деятельность ОБСЕ в основном носит реактивный характер, она осуществляется в ответ на запросы государственных органов и вряд ли может реально повлиять на качество работы государственной службы. Они указывают на отсутствие данных о том, как организованные ОБСЕ зарубежные визиты и обучающие туры для государственных служащих, серии «круглых столов» 
и тренингов влияют на качество работы министерств, и ставят под сомнение содержание и актуальность их рекомендаций.

Проблема, по мнению экспертов и активистов, состоит и в том, что трудно определить реальных бенефициаров деятельности ОБСЕ. Так, они критиковали встречу действующего Председателя ОБСЕ Линде с представителями гражданского общества Казахстана за ее закрытый характер и непрозрачную процедуру отбора участников ${ }^{23}$. Высказывается также критика в адрес как приглашаемых ОБСЕ зарубежных экспертов, так и сотрудников программ в связи с их некомпетентностью и неосведомленностью о ситуации в Казахстане, что негативно влияет на имидж ОБСЕ.

Наряду с этой критикой представители гражданского общества и академических кругов отмечают положительные стороны деятельности ОБСЕ как в Казахстане, так и в целом. Они подчеркивают ее эффективность в содействии развитию сотрудничества государств-участников в военно-политическом, экономическом и экологическом измерениях безопасности. Они также положительно отмечают, что ОБСЕ предоставляет независимым организациям гражданского общества площадку для выражения их позиций, в первую очередь по вопросам человеческого измерения, например, на ежегодном Совещании по рассмотрению выполнения обязательств в области человеческого измерения в Варшаве.

\section{Заглядывая в будущее}

В среднесрочной перспективе подход и уровень участия Казахстана в ОБСЕ вряд ли изменятся. Он будет декларировать приверженность целям и ценностям организации и позиционировать ОБСЕ как один из своих внешнеполитических приоритетов. Но при этом ОБСЕ будет рассматриваться не как ключевой институт, а как одна из различных европейских и евразийских организаций.

Казахстан будет продолжать использовать ОБСЕ как дипломатическую площадку для повышения своего международного авторитета, в том числе путем лоббирования создания тематического центра ОБСЕ в Казахстане и продвижения своих дипломатов на ключевые посты в организации. Он и дальше будет поощрять региональные и субрегиональные проекты ОБСЕ, особенно в экономическом и экологическом измерении, в том числе по развитию транспортных коридоров, соединяющих Азию и Европу. Наконец, Казахстан будет и впредь придавать большое значение посредничеству и урегулированию конфликтов, особенно в Центральной Азии и Афганистане. 


\section{Примечания}

1 Cooper R. Russia, the West and Global Civilization // Russia and the West at the Millennium: Global Imperatives and Domestic Policies / S. Medvedev, A. Konovalov, S. Oznobishchev (eds.). - Garmisch-Partenkirchen: George C. Marshall European Center for Security Studies, 2003. - Р. 22.

2 См. Президент Республики Казахстан. Указ от 29 августа 2008 года № 653 «О Государственной программе "Путь в Европу" на 2009-2011 годы»// Информационно-правовая система нормативных правовых актов Республики Казахстан «Әділет». URL: http://adilet.z an.kz/rus/docs/U080000653_.

3 Президент Республики Казахстан. Указ от 29 сентября 2017 года № 554 «Об утверждении Военной доктрины Республики Казахстан» // Информационно-правовая система нормативных правовых актов Республики Казахстан «Әділет». URL: http://adilet.zan.kz/rus/docs/ U1700000554.

4 Выступление Министра иностранных дел РК Б. Атамкулова в ходе неформального СМИД ОБСЕ // Посольство Республики Казахстан в Украине. - 2019. - 10 июля. URL: https://ww w.gov.kz/memleket/entities/mfa-kiev/press/news/details/49963?lang=ru.

Правительство Республики Казахстан. Постановление от 31 декабря 2020 года № 953 «Об утверждении Комплексного плана по реализации государственной политики в религиозной сфере Республики Казахстан на 2021-2023 годы» // Информационно-правовая система нормативных правовых актов Республики Казахстан «Әділет». URL: http://adilet.zan.kz/rus/ docs/P2000000953.

6 Постоянный совет ОБСЕ. Решение № 1364. Продление срока действия мандата Программного офиса ОБСЕ в Нур-Султане // Официальный сайт ОБСЕ. - 2019. - 19 декабря. URL: https://www.osce.org/files/f/documents/c/e/444271.pdf.

Президент Республики Казахстан. Указ от 6 марта 2020 года № 280 «О Концепции внешней политики Республики Казахстан на 2020-2030 годы» // Информационно-правовая система нормативных правовых актов Республики Казахстан «Әділет». URL: http://adilet.z an.kz/rus/docs/U2000000280.

Anghelescu A.-M. Does It Matter That the New OSCE High Commissioner for National Minorities Is from Kazakhstan? // The Diplomat. - 2020. - 16 December. URL: https://thediplomat.co $\mathrm{m} / 2020 / 12 /$ does-it-matter-that-the-new-osce-high-commissioner-for-national-minorities-is-from -kazakhstan/.

Саммит ОБСЕ-2010: Казахстан как региональный и мировой лидер // Библиотека Первого Президента Республики Казахстан - Елбасы. 2020. 7 декабря. URL: https://elbasylibrary. gov.kz/ru/news/sammit-obse-2010-kazahstan-kak-regionalnyy-i-mirovoy-lider. См. также: Международная онлайн-конференция «Астанинский саммит ОБСЕ 2010: историческое значение и актуальность» // Министерство иностранных дел Республики Казахстан. 2021. 19 февраля. URL: https:/www.gov.kz/memleket/entities/mfa/press/news/details/163332?lang=r u.

10 Казахстанский дипломат избран Верховным комиссаром ОБСЕ по делам национальных меньшинств // Министерство иностранных дел Республики Казахстан. 2020. 4 декабря. URL: https://www.gov.kz/memleket/entities/mfa/press/news/details/131951?lang=ru.

11 Внешнеполитические инициативы Казахстана представлены в ходе заседания СМИД ОБСЕ // Посольство Республики Казахстан в Украине. 2019. 6 декабря // https://www.go v.kz/memleket/entities/mfa-kiev/press/news/details/51524?lang=ru.

12 Председатель ОБСЕ прибыла в Казахстан // Хабар 24. - 2021. - 12 апреля. URL: https://24. $\mathrm{kz} / \mathrm{ru} / \mathrm{news} /$ policy/item/467167-predsedatel-obse-pribyla-v-kazakhstan. 


\section{Рустам Бурнашев и Ирина Черных}

13 Постоянный совет ОБСЕ. Решение № 1364. Продление срока действия мандата Программного офиса ОБСЕ в Нур-Султане.

14 Казахстан укрепляет сотрудничество со странами Центральной Азии в рамках ОБСЕ // Посольство Республики Казахстан в Республике Австрия, Постоянное Представительство при международных организациях в городе Вена. 2020. 21 мая. URL: https://www.gov.kz/m emleket/entities/mfa-vienna/press/news/details/kazahstan-ukreplyaet-sotrudnichestvo-so-stranam i-centralnoy-azii-v-ramkah-obse?lang=ru.

15 Нурсултан Назарбаев предложил новую геополитическую реальность «Три Д» // Официальный сайт Президента Республики Казахстан «Акорда». 2019. 27 апреля. URL: https://w ww.akorda.kz/ru/events/international_community/foreign_visits/nursultan-nazarbaev-predlozhil -novuyu-geopoliticheskuyu-realnost-tri-d.

16 СМИД ОБСЕ: на повестке дня усиление роли ОБСЕ в решении вопросов глобальной и региональной безопасности // Министерство иностранных дел Республики Казахстан. 2017. 8 декабря. URL: https://www.gov.kz/memleket/entities/mfa/press/news/details/30397?lan $\mathrm{g}=\mathrm{ru}$.

17 Кайрат Абдрахманов встретился с Генеральным секретарем ОБСЕ // Baige News. - 2018. 11 октября. URL: https://baigenews.kz/news/kairat_abdrahmanov_vstretilsya_s_generalnim_se kretarem_obse/.

18 Конырова К. Казахстан вышел с инициативой о необходимости созыва нового саммита ОБСЕ // Информационное агентство «Inbusiness.kz». - 2021 - 19 февраля. URL: https://inb usiness.kz/ru/news/kazahstan-vyshel-s-iniciativoj-o-neobhodimosti-sozyva-novogo-sammita-obs e.

19 Выступление Министра иностранных дел РК Б. Атамкулова в ходе неформального СМИД ОБСЕ.

20 Назарбаев Н. Судьба и перспективы ОБСЕ // Известия. - 2010. - 28 января. URL: https://iz. $\mathrm{ru} /$ news/357755.

21 Там же.

22 Chernykh I., Burnashev R., Dzardanova S. et al. Central Asian Narratives on the OSCE. Research report of the OSCE Network of Think Tanks and Academic Institutions, 2019.

23 Председатель ОБСЕ встретилась в Нур-Султане с представителями гражданского общества // Радио Азаттык. - 2021. - 13 апреля // https://rus.azattyq.org/a/31201040.html. 


\title{
Швеция и ОБСЕ
}

\author{
Ларс-Эрик Лундин ${ }^{*}$
}

\section{Аннотаичя}

Приняв обязанности Председателя ОБСЕ в 2021 году, Швеция предложила организации вернуться к основам, сосредоточившись на соблюдении принятых в рамках организации обязательств и ключевых принципов, закрепленных в хельсинкском Заключительном акте 1975 года. Несоблюдение этих принципов Швеция воспринимает как угрозу для европейской безопасности в целом и безопасности Швеции в частности. Поэтому в период своего председательства страна сосредоточила внимание на трех приоритетах: сохранении системы европейской безопасности, укреплении всеобъемлющего подхода ОБСЕ к безопасности, в частности, в том, что касается ее «человеческого измерения», и содействии урегулированию конфликтов путем осуществления политики «малых шагов» при непосредственном и активном участии Председателя. Шведское государство уделяет особое внимание феминистской составляющей внешней политики, рассматривая в качестве фундаментальной цели обеспечение гендерного равенства и повышение роли женщин в деятельности ОБСЕ по обеспечению мира и безопасности.

\section{Возвращение к основам}

Одним из главных побудительных мотивов выдвижения кандидатуры Швеции на председательство в ОБСЕ в 2021 г. было стремление поддержать многосторонний подход, который после окончания Второй мировой войны стал важной частью внешней политики страны ${ }^{1}$. Министр иностранных дел Швеции Анн Линде заявила, что руководящим принципом председательства Швеции будет «возвращение к основам», имея в виду необходимость восстановить уважение к фундаментальным принципам организации и обеспечить ее дееспособность ${ }^{2}$.

Швеция обладает сорокалетним опытом содействия успешному функционированию ОБСЕ. В 1984-1986 гг. она в течение трех лет принимала стокгольмскую конференцию, сыгравшую роль первопроходца в сфере контроля над вооружениями и мер укреплению доверия и безопасности. В 1993 г. она стала одним из первых Председателей ОБСЕ. С 2001 по 2004 г. Рольф Экеус занимал один из ведущих постов в организации в качестве Верховного комиссара по делам национальных

* Ларс-Эрик Лундин

Стокгольмский международный институт исследования проблем мира (SIPRI),

larserik.lundin@gmail.com. 
меньшинств. Швеция неизменно участвует в коллективных усилиях по укреплению ОБСЕ как международной организации, несмотря на отсутствие у нее общепризнанной международной правосубъектности. Готовясь к своему председательству, шведская делегация в Вене в 2020 г. работала вместе с албанским Председателем, внося свой вклад в повседневную деятельность ОБСЕ и принятие решений. Учитывая пандемию коронавируса и летний кризис руководства ОБСЕ, 2020 год был сложным для организации.

Заявленное Швецией намерение вернуться к основам относится прежде всего к восстановлению уважения к фундаментальным принципам, закрепленным в хельсинкском Заключительном акте 1975 г. и парижской Хартии 1990 г. Обязательства, принятые в этих исторических документах на основе консенсуса, стали фундаментом для обеспечения демократии, прав человека и верховенства права во всем регионе от Ванкувера до Владивостока. Государства-участники подтвердили эти обязательства на саммите ОБСЕ в Астане в 2010 г. ${ }^{3}$, но как на Востоке, так и на Западе мы все еще сталкиваемся с отступлениями от них. Речь идет в том числе об отступлениях от принципов суверенного равенства и территориальной целостности государств, что Швеция воспринимает как угрозу для европейской системы безопасности в целом и своей национальной безопасности в частности. Поэтому обеспечение соблюдения основополагающих принципов - важнейший элемент политики безопасности Швеции и ее ожиданий, связываемых с ОБСЕ.

\section{В центре внимания - «жесткая» безопасность}

В широком контексте шведской политики безопасности сегодня считается, что ситуация в сфере безопасности в регионе ОБСЕ в последние годы стала более сложной. В конце 1990-х гг. Швеция еще считала, что подходы государств-участников к демократии, правам человека и верховенству права сближались. Временами то тут, то там наблюдались отступления от этой тенденции, но в целом казалось, что ситуация постепенно улучшалась. Региональные конфликты были сосредоточены, по мнению Швеции, на периферии региона ОБСЕ, в Юго-Восточной и Восточной Европе, на Кавказе и в Центральной Азии. Однако через несколько лет после начала нового тысячелетия противодействие России так называемым «цветным революциям» в Украине и Грузии стало сигналом того, что многообещающая ситуация, сложившаяся по окончании «холодной войны» постепенно стала меняться в худшую сторону. Аннексию Крыма (части территории одного из государств-участников) военным путем Швеция восприняла как серьезное предупреждение о деградации обстановки в области безопасности в регионе ОБСЕ.

Для Швеции отступление от соблюдения ключевых принципов ОБСЕ в последние годы имеет серьезные военные последствия. Ее беспокоит опасность военной эскалации, не в последнюю очередь с учетом огромных ядерных арсеналов, раз- 
мещенных в европейской части России. Напряженная обстановка, сложившаяся в Беларуси в 2021 г., приблизила проблемы предотвращения и урегулирования конфликтов к границам Швеции. Быстрое развитие военных технологий и других инструментов применения силы, в том числе в киберпространстве, также приблизило к Швеции затяжные конфликты в регионе ОБСЕ. Страдания людей в условиях возобновившегося вооруженного противостояния вокруг Нагорного Карабаха продемонстрировали разрушительный потенциал таких конфликтов.

На этом фоне Швеция восстанавливает свою запущенную систему территориальной обороны страны и укрепляет двустороннее и многостороннее сотрудничество ${ }^{4}$. С 1994 года она участвует в программе НАТО «Партнерство ради мира». Как страна-член ЕС она имеет юридические обязательства о солидарности, дополненные односторонней декларацией о солидарности со странами Северной Европы, к которым относятся в том числе не входящие в ЕС Исландия и Норвегия. Наконец, Швеция и США подписали заявление о намерениях относительно двустороннего оборонного сотрудничества. Особенно тесное оборонное сотрудничество связывает страну с Финляндией.

В то же время Швеция считает, что сдерживание должно быть дополнено усилиями по укреплению доверия. Согласно официальной политике Швеции, переговоры по вопросам «жесткой», военной безопасности, в том числе о ядерном оружии не должны вестись без участия наиболее важных держав на основе формального равенства. Именно здесь свою роль может сыграть ОБСЕ как форум, в рамках которого Запад и Восток могут поддерживать диалог и сотрудничество.

Швеция поддерживает укрепление ОБСЕ как площадки для сотрудничества в таких форматах, как «структурированный диалог» по современным и будущим вызовам и рискам для безопасности. «Структурированный диалог» предоставляет возможность для прямого общения между представителями 57 государств на уровне экспертов. В продолжение своей деятельности в качестве председателя Форума ОБСЕ по сотрудничеству в области безопасности в 2018 г. ${ }^{5}$, Швеция содействует усилиям, направленным на укрепление контроля над вооружениями, а также на сохранение жизнеспособности и эффективное функционирование Венского документа и Договора по открытому небу 6 . Однако начать предметный диалог по этим вопросам сложно, поскольку Россия и другие крупные державы противятся обсуждению их военных потенциалов, особенно ядерных в рамках многосторонних переговоров. Тем не менее, поскольку Россия начала серьезно противодействовать процессам расширения ЕС и НАТО, необходимость возродить всеобъемлющий диалог становится все более насущной.

Как Председатель ОБСЕ Швеция считает приоритетными усилия по урегулированию затяжных конфликтов в регионе ОБСЕ. Важными задачами остаются поддержание режима прекращения огня в Украине и обеспечение прогресса в урегулировании приднестровского конфликте в Молдове. Швеция давно видит опасность распространения конфликтов, продолжающихся в странах за пределами региона 
ОБСЕ, включая Афганистан. Действующий Председатель обсуждала эту проблему в ходе общения с коллегами из Центральной Азии.

\section{Отстаивание «человеческого измерения» ОБСЕ}

«Человеческое измерение» с самого начала было важной частью всеобъемлющего подхода ОБСЕ к безопасности и имеет центральное значение для Швеции. Оно включает вопросы прав человека, демократии и верховенства права, но связано также с экономико-экологическими принципами второго измерения ОБСЕ и, конечно, с проблематикой прав национальных меньшинств и безопасности человека, которая традиционно относится к первому измерению ОБСЕ - безопасности. Приверженность Швеции нормам, принятым в рамках «человеческого измерения» и закрепленным в парижской Хартии 1990 г. и последующих документах ОБСЕ, принятых после окончания «холодной войны», была необходимым условием для успешной интеграции страны в международное сообщество. Эта приверженность воплотилась в международно-правовых обязательствах, принятых Швецией в рамках различных международных организаций, включая ЕС и Совет Европы.

В настоящее время вопросы «человеческого измерения» ОБСЕ вызывают трения между государствами-участниками, поэтому политика Швеции в данной области определяется как озабоченностью, так и амбицией. Обсуждение в ОБСЕ обязательств в области «человеческого измерения» теперь касается не только восточной части региона. В его западной части также наблюдается отступление от принятых в рамках организации обязательств, о чем свидетельствуют проявления популизма и ксенофобии, усилившиеся особенно после миграционного кризиса 2015 г. Это деликатный вопрос для Швеции в контексте как ее предстоящего в 2023 г. председательства в Совете ЕС, так и сотрудничества с Польшей, председательствующей в ОБСЕ в 2022 г.

Правительство Швеции считает, что ОБСЕ предпринимает еще недостаточно усилий для выполнения по крайней мере одного из ее обязательств - повышения роли женщин в предотвращении и урегулировании конфликтов и в миростроительстве. Хотя в реализации глобальной повестки дня «Женщины и мир и безопасность», инициированной резолюцией 1325 Совета Безопасности ООН, за последние два десятилетия был достигнут очень скромный прогресс, Швеция считает, что данное направление сотрудничества между государствами-участниками ОБСЕ не безнадежно даже в условиях современного политического климата. Об этом свидетельствует, в частности, посвящение Экономико-экологического форума ОБСЕ проблемам расширения экономических прав и возможностей женщин. 


\section{Политика малых шагов}

Швеция стала Председателем ОБСЕ в условиях неопределенности возможных последствий внутриполитических изменений в ключевых странах (к примеру, в результате избрания Джо Байдена президентом США) для функционирования многосторонних организаций и ОБСЕ. С учетом этого подход шведского Председателя заключался в том, чтобы предпринимать малые шаги, подкрепляемые частым взаимодействием на уровне министров.

Действующий Председатель, министр иностранных дел Анн Линде, сделала ряд публичных заявлений, в том числе в Совете Безопасности $\mathrm{OOH}^{7}$, и часто посещала районы конфликтов. Она провела двустороннюю встречу с министром иностранных дел России ${ }^{8}$ и выступила на обширных слушаниях, организованных Хельсинкской комиссией США 9 . В начале 2021 г. вместе со своими специальными представителями она предприняла ряд поездок на места ${ }^{10}$.

Шведская председательствующая сторона считала важным взаимодействие с институтами ОБСЕ и полевыми операциями, чтобы определить области потенциального взаимодействия и прогресса в современных политических условиях, избегая дублирования с деятельностью других международных организаций. Основное внимание уделялось работе на местах и усилению внимания к вопросам безопасности на уровне общин. Примером такой деятельности моет служить поддержка, оказываемая Программным офисом ОБСЕ в Бишкеке женским организациям, стремящимся снизить остроту проблемы межэтнического насилия в Оше и других населенных пунктах на юге Кыргызстана. В регионах, в которых сохраняются латентные конфликты, таких как Центральная Азия, Швеция стремится содействовать их урегулированию.

\section{Заключение и рекомендации}

Шведский подход к безопасности характеризуется стремлением обходить политические препятствия, проводя политику «малых шагов». Исходя из уроков, извлеченных страной в период ее председательства, можно сформулировать ряд рекомендаций, реализация которых будет способствовать дальнейшему движению ОБСЕ вперед ${ }^{11}$. Швеция пришла к выводу о том, что сначала следует достичь согласия о порядке действий и уже затем - по существу вопроса, и что проблемы следует решать исходя из местных условий, а не искать их глобальные решения. Пользу принесло сосредоточение усилий в тех областях сотрудничества, которые вызывают меньше всего споров, таких как второе (экономическое и экологическое) измерение или противодействие общим, в частности, транснациональным угрозам и вызовам. Швеция считала важным наладить диалог со столицами (а не только в Вене) и использовать неформальные каналы для общения. Наконец, деятельность Швеции 
в качестве Председателя ОБСЕ в условиях пандемии коронавируса потребовала творческого подхода в том, что касается методов продолжения работы, несмотря на кризис, используя, в частности, новые возможности в области цифровой коммуникации. Такие инновации следует развивать и дальше, чтобы превратить ОБСЕ в центр диалога между государствами-участниками и гражданским обществом.

\section{Примечания}

1 Интервью и дискуссии с представителями Председателя проводились неофициально. Серия из одиннадцати подкастов, подготовленных автором с участием официальных представителей Председателя и ключевых экспертов, доступна в виде плейлиста SoundCloud. URL: https://soundcloud.com/lars-erik-lundin/sets/podcasts-om-osse. См. также: Folk och Försvar [Люди и оборона], "The OSCE and the future of European security" // YouTube. 2021. 6 May. URL: https://www.youtube.com/watch?v=9zNlUa_OpKY\&gtk.

2 Cм.: Helsinki Commission, Hearing: Sweden's Leadership of the OSCE // YouTube. 2021. 11 June. URL: https://www.youtube.com/watch?v=iCsDyle6Xng\&amp;t=4s\&gt.

3 Астанинская юбилейная декларация: на пути к сообществу безопасности. 2 декабря 2010 // Официальный сайт ОБСЕ. URL: https://www.osce.org/ru/cio/74990.

4 Objectives for Swedish total defence 2021-2025 - Government bill 'Totalförsvaret 20212025' // Government Offices of Sweden. 2020. 18 December. URL: https://www.governmen t.se/government-policy/defence/objectives-for-swedish-total-defence-2021-2025---government-b ill-totalforsvaret-20212025/.

5 Address by Mr. Jan Salestrand, State Secretary to the Minister for Defence, Sweden, at the opening session of the Forum for Security Co-operation, Vienna, September 5, 2018. Document FSC.DEL/145/18, 6 September 2018 // Официальный сайт ОБCE. URL: https://www.osce.org/ files/f/documents/b/8/393464.pdf.

6 Johan Huovinen on confidence- and security-building measures in the OSCE // SoundCloud, December 2020. URL: https://soundcloud.com/lars-erik-lundin/forutsattningarna-for-fortroen de-och-sakerhetsskapande-atgarder-i-osse. См. также заявления Анн Линде на слушаниях Хельсинкской комиссии США (начиная с 32 минуты): Appearance at Helsinki Commission by Ann Linde // YouTube. 2021. 11 June. URL: https://www.youtube.com/watch?v=iCsDyle6X $\mathrm{ng} \& \mathrm{t}=4 \mathrm{~s}$.

7 Briefing by H.E. Ms. Ann Linde, Minister for Foreign Affairs of Sweden and OSCE Chairperson-in-Office to the United Nations Security Council // Government Offices of Sweden. 2021. 10 March. URL: https://www.government.se/speeches/2021/03/briefing-by-h.e.-ms.-ann-linde-m inister-for-foreign-affairs-of-sweden-and-osce-chairperson-in-office-to-the-united-nations-securi ty-council/.

8 OSCE Chairperson-in-Office Ann Linde discusses OSCE agenda with Russian Foreign Minister Lavrov in Moscow // Официальный сайт ОБСЕ. 2021. 3 February. URL: https://www.osce.org/ chairmanship/477439.

9 Выступление Линде в Хельсинкской комиссии с кратким изложением итогов деятельности и приоритетов Председателя в первые пять месяцев см.: Hearing: Sweden's Leadership of the OSCE // YouTube. 2021. 11 June. URL: https://www.youtube.com/watch?v=iCsDyle6Xn g\&amp;t=4s\&gt.

10 См., в частности: OSCE Chairperson-in-Office Linde concludes official visit to Ukraine // Официальный сайт ОБСЕ. 2021. 16 June 2021. URL: https://www.osce.org/chairmanship/4898 $45 \&$ gt- 
11 Данные предложения основаны на результатах проведенного автором анализа, получивших положительный отклик со стороны представителей председательствующей стороны. Однако они не предвосхищают возможные результаты, которые могут быть достигнуты на встрече Совета министров ОБСЕ. 


\title{
Польша и ОБСЕ
}

\author{
Лукаш Кулеса*
}

\section{Аннотация}

Все больше ощущая угрозу в связи с развитием ситуации в области безопасности к востоку от ее границ и стремясь получить ощутимые гарантии безопасности, Польша склонна считать ОБСЕ малозначимой организацией. Однако утверждение ее кандидатуры на председательство в ОБСЕ в 2022 г. временно изменило отношение Варшавы к ОБСЕ, которая в остальном в польской внешней политике и политике безопасности остается в тени НАТО и ЕС. Несмотря на ограниченный общественный, экспертный и академический интерес к ОБСЕ, Польша ценит уникальные особенности организации и намерена активно участвовать в ее работе в рамках всеобъемлющего подхода к безопасности с акцентом на повышение эффективности военно-политического измерения и роли ОБСЕ в зонах конфликтов, особенно в Восточной Европе. В то же время с учетом крайне враждебных отношений между государствами-участниками и внутренних проблем, сказывающихся на функционировании ОБСЕ, Польша не возлагает больших надежд на способность организации решать важнейшие проблемы безопасности в Европе.

\section{Введение}

Значимость ОБСЕ для Польши временно возросла после утверждения ее кандидатуры на председательство в организации в 2022 г. В качестве будущего председателя Польша расширила свое участие в работе ОБСЕ. С января 2021 г. она входит в «тройку» и председательствует в Группе ОБСЕ для средиземноморских партнеров по сотрудничеству. Вполне вероятно, что 2022 год станет для польской дипломатии «годом ОБСЕ». Как заявил в июле 2021 г. министр иностранных дел Збигнев Рау, Польша «приложит все усилия для оказания содействия государствам-участникам в развитии диалога на основе принципов и обязательств ОБСЕ» ${ }^{1}$. Тем не менее возрастание внимания к организации не следует воспринимать как свидетельство серьезного сдвига в восприятии Польшей значимости организации или ее готовности возглавить новаторские инициативы в ОБСЕ.

\footnotetext{
* Лукаш Кулеса

Польский институт международных отношений, kulesa@pism.pl.
} 


\section{Место ОБСЕ во внешней политике и политике безопасности Польши}

Все больше ощущая угрозу в связи с развитием ситуации в сфере безопасности к востоку от ее границ и стремясь получить ощутимые гарантии безопасности, Польша не склонна полагаться на ограниченные возможности ОБСЕ. Еще до оккупации Россией Крыма ее роль во внешней политике и политике безопасности страны была практически незаметна в сравнении с НАТО и $\mathrm{EC}^{2}$. Политика безопасности страны базируется на четырех взаимодополняющих основах: членство в НАТО и ЕС, партнерство в сфере безопасности с США и региональное сотрудничество в сфере безопасности. После ухудшения отношений с Россией для Польши существенно возросло значение структур и отношений, которые обеспечивают ей надежные возможности для сдерживания и влияния. В этих условиях ОБСЕ имеет ограниченную ценность по сравнению с НАТО как поставщиком твердых гарантий безопасности и ЕС с его всеобъемлющим Восточным партнерством и восточной политикой в отношении России и Центральной Азии.

ОБСЕ часто упоминается в польских документах стратегического планирования, хотя ее роль не прописана в деталях. Например, Стратегия национальной безопасности до 2020 г. предусматривает лишь, что Польша будет «предпринимать шаги для повышения эффективности [...] Организации по безопасности и сотрудничеству в Европе как жизненно важной части системы европейской безопасности, основанной на сотрудничестве» ${ }^{3}$. Если не считать публикации бывшего министра иностранных дел и специалиста по вопросам международной безопасности профессора Адама Даниэля Ротфельда, интерес к ОБСЕ со стороны общественности, СМИ, экспертов и ученых невелик ${ }^{4}$. Польская делегация в Парламентской ассамблее ОБСЕ активна, но ни парламент, ни его комитеты по иностранным делам в последнее время не проводили слушания по тематике ОБСЕ.

Однако это не делает ОБСЕ неактуальной для Польши. Страна признает ее особую роль как региональной организации по безопасности, основанной на хорошо разработанном комплексе общих принципов и обязательств, с инклюзивным членством и важными историческими достижениями. Организация является одной из опор основанного на правилах международного порядка, в поддержании которого Польша заинтересована. Объясняя причины выдвижения кандидатуры страны на пост председателя ОБСЕ, министр иностранных дел Яцек Чапутович отметил, что Польша высоко ценит роль организации в укреплении стабильности в Европе и готова выступать в качестве «беспристрастного посредника», содействующего развитию сотрудничества ${ }^{5}$.

К тому же существует прямая связь между повесткой дня ОБСЕ и региональными приоритетами внешней политики и политики безопасности Польши. В первую очередь это касается Восточной Европы и Южного Кавказа, Западных Балкан и Центральной Азии. Первое (военно-политическое) измерение безопасности в деятельности организации важно для достижения целей Польши по повышению транс- 
парентности и предсказуемости военной деятельности. Наконец, ОБСЕ остается форумом, на котором Польша может артикулировать свою позицию по важным вопросам европейской безопасности и оказывать дополнительное давление на белорусский режим и Россию.

\section{Восприятие роли и возможностей ОБСЕ}

Польша исходит из того, что регион ОБСЕ сталкивается с рядом вызовов, включая продолжающиеся конфликты, политические кризисы и субрегиональные очаги напряженности, ряд транснациональных угроз и проблемы, вызванные пандемией коронавируса. Однако сама ОБСЕ не рассматривается ею как организация, способная сыграть решающую роль в решении этих проблем. Поэтому Польша придерживается прагматичного, приземленного подхода к роли и повестке дня ОБСЕ. Она настороженно относилась к призывам наделить ОБСЕ статусом центральной организации в системе европейской безопасности или функциями по координации деятельности других региональных организаций. Это противоречило бы той центральной роли, которую Варшава в своей внешней политике отводит НАТО и ЕС, и способствовало бы повышению влияния России. Польша также не разделяет мнение о том, что некоторые из основополагающих принципов хельсинкского Заключительного акта, парижской Хартии и других документов ОБСЕ утратили свое значение и что государства не должны быть подотчетны организации, а самой ОБСЕ следует просто принять тот факт, что ряд государств-участников являются авторитарными режимами.

Польша не возлагает больших надежд на способность ОБСЕ урегулировать кризисы в сфере европейской безопасности. В условиях оккупации Россией Крыма и ее присутствия в регионах Донецка и Луганска, а также российско-грузинского, нагорнокарабахского и приднестровского конфликтов интересы вовлеченных в них сторон сильно расходятся, а организация не имеет ни политического веса, ни инструментов, необходимых для того, чтобы повлиять на позиции сторон и обеспечить прочное урегулирование. Однако она может использовать свой инструментарий урегулирования конфликтов для стабилизации обстановки в этих регионах, смягчения гуманитарных проблем и содействия диалогу. В этом отношении, например, положительно оценивается роль Специальной мониторинговой миссии (CMM) ОБСЕ в восточной Украине (Польша внесла свой вклад в работу миссии, командировав в ее состав свой персонал и обеспечив вакцинацию сотрудников СММ в июне 2021 г. $)^{6}$, но для долгосрочного урегулирования кризиса, с точки зрения Польши, в первую очередь потребуется изменение российской политики. Война в Нагорном Карабахе 2020 г. между Азербайджаном и Арменией также показала границы возможностей ОБСЕ в острой кризисной фазе «конфликтного цикла». 
Не следует ожидать, что ОБСЕ можно будет оградить от влияния эскалации напряженности в отношениях между государствами-участниками. Польша сама не уклоняется от критики государств, которые, по ее мнению, нарушают принципы и обязательства, принятые в рамках ОБСЕ. Она выступает за тесную координацию и согласование политических позиций стран НАТО и ЕС в Вене. В то же время она выражает озабоченность политизацией практически всех аспектов функционирования ОБСЕ, включая обсуждение бюджета и, казалось бы, рутинное продление мандатов полевых операций.

В Польше видят проблему в увязывании отдельными государствами не связанных или слабо связанных друг с другом вопросов для получения дополнительных рычагов влияния в ходе переговоров. Порой это приводит к тому, что организация становится заложницей требований одного государства-участника, часто касающихся очень локальных вопросов. Бывший Генеральный секретарь ОБСЕ Томас Гремингер приводит пример такой ситуации: блокирование реформы бюджетного процесса из-за разногласий по поводу оговорки в распространяемых в ОБСЕ документах о том, что секретариат «не несет ответственности за содержание» ${ }^{7}$. Следствием такого подхода стал кризис, возникший в 2020 г. вокруг продления мандатов глав институтов ОБСЕ и секретариата. Начавшись с возражений одного государства против продления мандата главы одного из институтов ОБСЕ, этот спор перерос в более масштабный кризис, который привел к тому, что в июле 2020 г. не были продлены полномочия Генерального секретаря, Представителя по вопросам свободы СМИ, Верховного комиссара по делам национальных меньшинств (ВКНМ) и директора Бюро по демократическим институтам и правам человека (БДИПЧ) ${ }^{8}$.

Одним словом, Польша рассматривает ОБСЕ как важный, но не центральный элемент архитектуры европейской безопасности и соответствующим образом корректирует связываемые с организацией ожидания и взаимодействие с ней. Несмотря на имеющиеся недостатки, нормативная база ОБСЕ и ее всеобъемлющий подход к безопасности рассматриваются как положительные факторы. Польша также ценит практический вклад организации на местах, особенно в зонах конфликтов.

\section{Участие Польши}

Польша имеет достойный опыт взаимодействия с ОБСЕ. На ее территории располагается БДИПЧ и проходит ежегодное Совещание по рассмотрению выполнения обязательств в области человеческого измерения - крупнейшая в Европе регулярная встреча по правам человека. В 1998 г. Польша председательствовала в ОБСЕ, а польские дипломаты занимали важные посты в организации. Посол Адам Коберацкий в 2011-2015 гг. возглавлял Центр ОБСЕ по предотвращению конфликтов, а посол Анджей Каспшик с 1996 г. является личным представителем действующего 
Председателя ОБСЕ по конфликту, являющемуся предметом рассмотрения на Минской конференции ОБСЕ (Нагорный Карабах).

Решение предложить свою кандидатуру на председательство в ОБСЕ свидетельствует о том, что Польша исходит из того, что ответственность за европейскую и евразийскую безопасность не позволяет ей ограничиваться только членством в НАТО и ЕС. Этот вывод согласуется с более широкими международными амбициями Польши, являвшейся в 2018-2019 гг. непостоянным членом Совета Безопасности ООН. В этот период страна сосредоточила внимание на темах, имеющих отношение к ее предстоящему председательству в ОБСЕ: укрепление международного права, защита гражданского населения в вооруженных конфликтах и ситуация в области безопасности в Восточной Европе. Представляя в июле 2021 г. контуры программы председательства Польши в ОБСЕ в 2022 г., министр иностранных дел Рау аккуратно сформулировал три цели, примерно соответствующие трем измерениям ОБСЕ: 1) поддержка деятельности ОБСЕ по урегулированию конфликтов, 2) реагирование на вызовы после пандемии коронавируса на основе эффективного мультилатерализма и 3) полное использование потенциала организации для обеспечения выполнения принятых в ее рамках общих обязательств.

Военно-политическое измерение было самым важным направлением деятельности Польши после общего ухудшения ситуации в сфере безопасности в Центральной Европе. Польша активно участвует в «структурированном диалоге» и в работе Форума по сотрудничеству в области безопасности, поднимая проблему несоответствия положений Венского документа 2011 г. о мерах укрепления доверия и безопасности современной деятельности вооруженных сил. Эта проблема стала актуальной в результате того, что, по мнению Польши, Россия выборочно выполняет или обходит важные положения Венского документа, заявляя, в частности, что проводимые ею военные учения не достигают пороговых значений для предварительного уведомления и приглашения наблюдателей, а также проводя крупномасштабные внезапные проверки боеготовности. Польша привлекала внимание к возросшей опасности военных инцидентов и призывала пересмотреть положения Венского документа, касающиеся уменьшения опасности, включая процедуры сотрудничества в отношении опасных инцидентов военного характера и необычной военной деятельности. Польша последовательно поддерживает модернизацию Венского документа. Она сформулировала свои предложения на этот счет, которые вошли в совместное предложение, выдвинутое группой государств в 2019 г. ${ }^{9}$ Поскольку Россия блокирует модернизацию Венского документа, Польша поддерживает идею применения добровольных мер по обеспечению транспарентности военной деятельности, включая проведение брифингов о военных учениях и деятельности.

Польша обеспокоена демонтажем европейской архитектуры контроля над вооружениями, являющейся неотъемлемой частью всеобъемлющего подхода ОБСЕ к безопасности. Она обвиняла Россию в подрыве Договора об обычных вооруженных силах в Европе и Договора о ракетах средней и меньшей дальности. Поддержи- 
вая продолжение действия Договора по открытому небу, она (как и Соединенные Штаты) ставила вопрос о введенных Россией ограничениях на осуществление наблюдательных полетов, особенно над территорией Калининградской области. Соответственно, Польша воздержалась от критики в адрес Соединенных Штатов после их выхода из договора в мае 2020 г., но с «разочарованием» отреагировала на заявление России о начале процедуры выхода из него в январе 2021 г.

Польша полностью поддерживает усилия по регулированию кризисов и деятельность ОБСЕ по поддержанию диалога в рамках различных форматов и процессов. В практическом плане в контексте своего председательства она планирует определить области, в которых участие ОБСЕ могло бы изменить положение дел и принести пользу пострадавшим от конфликта людям и группам населения, особенно наиболее уязвимым группам ${ }^{10}$. В этом отношении Польша стремится лучше координировать свою собственную программу международной помощи с деятельностью ОБСЕ.

Экономическому и экологическому измерению деятельности ОБСЕ в Варшаве уделяется меньше внимания, чем другим. Планы Польши в этой области определяются прагматичной целью увязать деятельность ОБСЕ с деятельностью других организаций, таких как $\mathrm{OOH}, \mathrm{EC}$ и Организация экономического сотрудничества и развития. Польша ожидает, что ОБСЕ будет опираться на деятельность других организаций по поддержке устойчивого восстановления после пандемии. Она скорее всего и дальше будет подчеркивать взаимосвязь между экономическим развитием и борьбой с отмыванием денег, поддерживать усилия ОБСЕ в этом отношении, подчеркивая свой собственный опыт в ужесточении фискальной системы и сокращении теневой экономики.

В том, что касается борьбы с изменением климата, Варшава скорее всего обратит внимание на результаты 24-й Конференции сторон Рамочной конвенции ООН об изменении климата, которая состоялась в Польше в 2018 г., и особенно на принятый в Катовице Свод правил по реализации парижского климатического соглашения. В этой связи Польша подчеркивает важность «справедливого перехода», предполагающего защиту интересов стран, использующих различные источники энергии, и регионов, все еще зависящих от ископаемых видов топлива и углеродоемких отраслей промышленности. С этим вопросом тесно связано освещение трансграничного сотрудничества Польши в Карпатском регионе, направленного на противодействие деградации окружающей среды и защиту биологического разнообразия. В контексте экономических и экологических вопросов ОБСЕ главная цель Польши - повысить осведомленность об этих вопросах.

В рамках «человеческого измерения» Польша уделяет особое внимание ситуации в Беларуси. В сентябре 2020 г. она была в числе семнадцати государств, которые задействовали Московский механизм для расследования нарушений прав человека в этой стране. Польша по-прежнему крайне критически относится к белорусскому режиму, в том числе к преследованию им представителей польского меньшинства и журналистов ${ }^{11}$. Польша, скорее всего, будет настаивать на том, чтобы ситуация 
в Беларуси и ее последствия занимали важное место в повестке дня ОБСЕ, и будет стремиться использовать все имеющиеся инструменты ОБСЕ, чтобы повлиять на ситуацию в Беларуси и в других потенциальных кризисных точках. Ее более широкая повестка дня в области прав человека в период председательства, по-видимому, будет включать ряд взаимосвязанных вопросов, актуальных для всех государств-участников. К ним относятся права человека в цифровую эпоху, влияние пандемии на права человека, расширение экономических прав и возможностей женщин, свобода мысли, совести, религии и убеждений, а также защита и поддержка конкретных групп, таких как инвалиды, дети и молодежь. Польша также стремится содействовать защите прав человека в зонах конфликтов. Вопрос свободных и справедливых выборах и наблюдения за ними традиционно занимает важное место в польской повестке дня в рамках ОБСЕ.

Следует отметить, что внутренние события в Польше и работа ее избирательной системы (например, во время президентских выборов 2020 г.) ${ }^{12}$ стали предметом пристального внимания и критического анализа в рамках ОБСЕ. За последние годы Представитель ОБСЕ по вопросам свободы СМИ обращал внимание на несколько случаев, имевших место в Польше ${ }^{13}$.

Польша стремилась выступать в качестве добропорядочного члена сообщества государств-участников организации, проявляя активность во всех измерениях и во всех основных областях деятельности ОБСЕ и внося вклад в обсуждение стратегических вопросов будущего организации. Этот вклад включал участие как на правительственном («процесс Корфу» и «структурированный диалог»), так и на экспертном уровнях (участие профессора Ротфельда в Группе видных деятелей по европейской безопасности как общему проекту ${ }^{14}$ и в Инициативе по безопасности, основанной на сотрудничестве) ${ }^{15}$.

\section{Польша и сценарии будущего ОБСЕ}

Было бы преувеличением утверждать, что ОБСЕ занимает видное место в польской внешней политике и политике безопасности. В Польше хорошо понимают ограниченность возможностей организации и не рассчитывают на то, что современные кризисы европейской безопасности могут быть преодолены благодаря деятельности ОБСЕ или реализуемых в ее рамках отдельных инициатив (таких как подготовка «юбилейного» саммита в 2025 г.).

Как председатель ОБСЕ, Польша не рассчитывает стать движущей силой крупных перемен. Тем не менее она, похоже, искренне заинтересована в достижении скромных успехов в реализации собственных приоритетов и общей повестки дня организации, а также в беспристрастном исполнении обязанностей действующего Председателя, способствуя тем самым стабилизации региона ОБСЕ и эффективному функционированию организации. Учитывая вероятность того, что в ее деятельность 
на данном посту вмешаются непредвиденные события, в 2022 г. Польше, возможно, придется больше заниматься кризисным регулированием, чем осуществлением заранее намеченной программы.

В более отдаленной перспективе Польша скорее всего сохранит свое нынешнее отношение к ОБСЕ. Организация важна для страны как форум, в рамках которого она может продолжать диалог и секторальное сотрудничество даже с недружественными государствами - особенно тогда, когда другие каналы коммуникации не работают или сильно ограничены. Хотя использование механизмов ОБСЕ может не увенчаться успехом в деле урегулирования существующих в Европе конфликтов, организация способна предоставить инклюзивную площадку для обеспечения прогресса в других областях.

В том маловероятном случае, если политические интересы США, России и ведущих европейских стран совпадут в том, что касается необходимости реального укрепления европейской безопасности, восприятие Польшей роли и значения ОБСЕ сразу изменится. Польша, вероятно, будет активно участвовать во всех обсуждениях в рамках ОБСЕ путей восстановления общеевропейской системы безопасности. Но при этом она прежде всего будет обращать внимание на свидетельства фундаментально изменившегося подхода России и не поддержит решения, которые обеспечили бы Москве слишком большую роль или предоставили бы ей право вето при принятии решений, влияющих на развитие ситуации в регионе общего соседства.

В более пессимистичном сценарии экзистенциального кризиса ОБСЕ, который мог бы быть вызван, к примеру, угрозой или фактическим выходом из организации какого-либо государства-участника ${ }^{16}$ или препятствованием ее деятельности, Польша, конечно, попытается (вместе с другими государствами-единомышленниками) разрядить ситуацию. В то же время она вряд ли согласится принять чрезмерные требования какого-либо государства, которое попыталось бы заставить организацию адаптироваться к его предпочтениям.

\section{Примечания}

1 Minister Zbigniew Rau takes part in OSCE Permanent Council meeting in Vienna // MFA Press Office. 2021. 15 July. URL: https://www.gov.pl/web/diplomacy/minister-zbigniew-rau-takes-par t-in-osce-permanent-council-meeting-in-vienna.

2 CM.: Bużański M. Poland - Flexibility to Address a Broad Area of Subjects // Perceptions of the OSCE in Europe and the USA / A. Dienes, R. Krumm (eds.). - Vienna: FES Regional Office for Cooperation and Piece in Europe, 2018. P. 76-77.

3 National Security Strategy of the Republic of Poland. 12 May 2020. P. 25. URL: https://www.bb n.gov.pl/ftp/dokumenty/National_Security_Strategy_of_the_Republic_of_Poland_2020.pdf.

4 См., напр.: Rotfeld A. D. A Euro-Atlantic and Eurasian Security Community: A New Role for the OSCE // OSCE Yearbook 2013 / IFSH (ed.). - Baden-Baden: Nomos, 2014. P. 53-66. URL: https://ifsh.de/file-CORE/documents/yearbook/english/13/Rotfeld-en.pdf. 
CM.: Poland to chair OSCE in 2022 // MFA Press Office. 2019. 5 December. URL: https://www. gov.pl/web/osce/poland-to-chair-the-osce-in-2022.

6 По состоянию на декабрь 2020 г. тридцать шесть польских граждан были командированы в состав СММ и один польский гражданин - в состав миссии наблюдателей ОБСЕ на украинско-российской границе.

7 Cм.: Greminger T. Making the OSCE More Effective: Practical Recommendations from a Former Secretary General // OSCE Insights. 2021. No 1 / IFSH (ed.). - Baden-Baden: Nomos, 2022. P. 5-6. URL: https://www.nomos-elibrary.de/10.5771/9783748911456-01/making-the-osc e-more-effective-practical-recommendations-from-a-former-secretary-general?hitid=2\&search-cl ick.

8 Подробнее см.: Kemp W. Executed structures: Leadership crisis in the OSCE // Security and Human Rights Monitor. - 2020. - 14 July. URL: https://www.shrmonitor.org/executed-structure s-leadership-crisis-in-the-osce/.

9 См.: Germany presents proposals to the OSCE on adjusting the Vienna document. Federal Foreign Office Press Release. 2019. 23 October. URL: https://www.auswaertiges-amt.de/en/new sroom/news/annen-vienna-document-osce/2259666.

10 См.: Интервью с сотрудником МИДа. Май 2021 г.

11 См.: Joint statement invoking the Moscow Mechanism in relation to serious human rights violations in Belarus // Ministry of Foreign Affairs of the Republic of Lithuania. 2020. 5 November. URL: https://urm.lt/default/en/news/joint-statement-invoking-the-moscow-mechanism-in-relatio n-to-serious-human-rights-violations-in-belarus.

12 См.: Republic of Poland. Presidential Elections 28 June and 12 July 2020. ODIHR Special Election Assessment Mission Final Report. 2020. 23 September // Официальный сайт ОБСЕ. URL: https://www.osce.org/odihr/elections/poland/464601.

13 См.: Press statements of the OSCE Representative on Freedom of the Media on Poland // Официальный сайт ОБСЕ. URL: https://www.osce.org/fom/statements/?filters=+im_taxonomy vid 5:\%28274\%29\&solrsort=ds date $\% 20$ desc\&rows $=10$.

14 См.: Panel of eminent persons // Официальный сайт ОБСЕ. URL: https://www.osce.org/networ $\mathrm{ks} / \mathrm{pep}$.

15 См. веб-сайт Инициативы по безопасности, основанной на сотрудничестве: https://www.co operative-security-initiative.org/.

16 См.: Кортунов А. Уйти или остаться? Семь российских претензий к ОБСЕ // Российский совет по международным делам. 2021. 19 мая. URL: https://russiancouncil.ru/analytics-and-c omments/analytics/uyti-ili-ostatsya-sem-rossiyskikh-pretenziy-k-obse/. 


\title{
Северная Македония и ОБСЕ
}

\author{
Ана Крстиновска*
}

\section{Аннотация}

В статье для специального выпуска ОБСЕ Insights перспективы взаимодействия Северной Македонии с ОБСЕ обсуждаются на основе анализа ожиданий страны, роли ОБСЕ в сравнении с другими международными организациями, а также проблем и возможностей, с которыми Северная Македония столкнется в период своего председательства в ОБСЕ в 2023 г. В статье утверждается, что несмотря на то, что ОБСЕ внесла существенный вклад в консолидацию страны в 1990-2000-е гг., по своей значимости для страны она уступает сегодня ЕС и НАТО. Тем не менее деятельность организации и, в частности, ее полевой операции в значительной мере способствует осуществлению реформ в Северной Македонии и тем самым - достижению ее стратегических целей, таких как вступление в ЕС и реализация целей устойчивого развития ООН. Северная Македония могла бы использовать свое председательство в 2023 г. для самоутверждения, повышения в стране интереса к ОБСЕ и, в более широком плане, для продолжения той роли, которую организация сыграла в стабилизации и трансформации страны.

\section{Введение ${ }^{1}$}

Республика Македония стала независимой в 1991 г. после распада Югославии. В июле 1992 г. она подписала хельсинкский Заключительный акт, а в сентябре того же года в стране была развернута полевая операция ОБСЕ, задачей которой было предотвращение распространения войн на территории бывшей Югославии. В 1993 г. деятельность ОБСЕ была дополнена миссией ООН, что позволило Северной Македонии избежать вооруженного конфликта. В результате страна считается «примером относительно успешной деятельности ОБСЕ по предотвращению конфликтов, в ходе которой прошли проверку возможности взаимодействия ОБСЕ и ООН в рамках их превентивных действий»².

Однако обстоятельства складывались не столь удачно после 1999 г., когда после войны в Косово и вывода Сил превентивного развертывания ООН обострение межэтнических отношений в Северной Македонии в 2001 г. вылилось во внутренний вооруженный конфликт. Хотя ОБСЕ не играла ведущую роль в обеспечении безопасности и достижении мира, ее Контрольная миссия по предотвращению рас-

\footnotetext{
* Ана Крстиновска

ESTIMA, Скопье, krstinovska@estima.mk.
} 
пространения конфликта внесла свой вклад в раннее предупреждение, решение проблем беженцев и начало переговоров сторон в конфликте и представителей международного сообщества ${ }^{3}$. Мир, достигнутый в результате посреднических усилий ЕС и США в августе того же года, был скреплен охридским Рамочным соглашением (ОРС), которое заложило основы общества, основанного на этническом, религиозном, культурном и языковом разнообразии.

В течение последующих двадцати лет реализация ОРС и, в частности, мер по укреплению доверия в межэтнических отношениях была одной из главных сфер взаимодействия страны с ОБСЕ. Хотя межэтнические отношения в Северной Македонии по-прежнему вызывают крайнюю озабоченность, а установленная ОРС консоциативная модель разделения власти стала источником непрекращающихся политических кризисов ${ }^{4}$, страна продвинулась вперед в плане примирения. Этим она отчасти обязана деятельности как Верховного комиссара ОБСЕ по делам национальных меньшинств, так и Контрольной миссии ОБСЕ в Скопье по предотвращению распространения конфликта (позднее она была преобразована в Миссию ОБСЕ в Скопье). После стабилизации обстановки в Северной Македонии первоначальный мандат ОБСЕ по предотвращению и урегулированию конфликтов в значительной степени исчерпал себя. Теперь организация воспринимается как партнер в процессе перехода страны к полноценно функционирующему демократическому государству.

Многолетняя деятельность развернутой в Северной Македонии полевой операции ОБСЕ и ее сотрудничество с ООН, ЕС и НАТО по урегулированию конфликтов вдохновили многочисленные исследования, посвященные эффективности созданных механизмов, их достижениям и ограничениям 5 . Эволюция мандата операции, сначала заключавшегося в предотвращении конфликта, а затем ориентированного на содействие примирению и государственному строительству, продемонстрировала способность ОБСЕ адаптироваться к меняющимся обстоятельствам и значимость ее долгосрочных операций ${ }^{6}$. Несмотря на наличие исследований, посвященных реализации менявшихся приоритетов миссии ОБСЕ и ее общей деятельности в Северной Македонии в 2000-е гг., а также роли ОБСЕ в конкретных областях политики ${ }^{7}$, мало что известно об успешности и устойчивости реформ, проводившихся при поддержке ОБСЕ. Практически нет объяснений и причин двойственного отношения правительства к ОБСЕ и ее присутствию в стране.

В статье анализируются перспективы взаимодействия Северной Македонии с ОБСЕ. Какие ожидания в Северной Македонии связывают с организацией? Какое место она занимает в сравнении с другими международными организациями и каковы потенциальные области для сотрудничества? Какие возможности и проблемы стоят перед Северной Македонией в период председательства в ОБСЕ? Работа основана на официальных документах, статьях в средствах массовой информации (СМИ), отчетах и полуструктурированных интервью с представителями государственных структур Северной Македонии, гражданского общества и Миссии ОБСЕ 
в Скопье. Она также основана на эмпирических наблюдениях автора во время ее работы в качестве советника по внешней политике, дипломата и чиновника в правительстве Северной Македонии в 2013-2018 гг.

\section{Интересы Северной Македонии и ОБСЕ}

Интересы, связываемые Северной Македонией с ОБСЕ, весьма прагматичны. Во многом это связано с тем, что страна еще не закончила разработку концепции своей внешней политики и приоритетов в двусторонних отношениях и многосторонних форумах $^{8}$. Хотя ОБСЕ по-прежнему считается в Северной Македонии одной из наиболее значимых международных организаций наряду с ООН, Всемирной торговой организацией и Советом Европы, она не имеет такого стратегического значения, как ЕС и $\mathrm{HATO}^{9}$. Более того, после вступления Северной Македонии в НАТО в марте 2020 г. появились признаки того, что она скорее всего сосредоточит сотрудничество в областях, связанных с безопасностью, в рамках НАТО и взаимодействия с союзниками, сократив масштабы сотрудничества с ОБСЕ. В результате центр тяжести во взаимодействии правительства с ОБСЕ постепенно смещается с первого (военно-политического) на второе (экономико-экологическое) и третье (человеческое) измерения, а сама организация по своей значимости уступает ЕС и НАТО. Тем не менее Северная Македония видит в предстоящем председательстве в ОБСЕ возможность укрепить свой международный авторитет и продемонстрировать свои институциональные возможности.

Программа реформ Северной Македонии определяется процессом ее вступления в ЕС - необходимостью привести внутреннее законодательство и стандарты в соответствие с законодательством ЕС. Учитывая, что и ЕС, и ОБСЕ осуществляют деятельность в таких сферах, как судебная система, СМИ, надлежащее управление, миграция, управление границами и права человека, деятельность ОБСЕ в стране во многом содействует ее интеграции в ЕС. Все эти направления относятся к важнейшему комплексу условий современной политики расширения $\mathrm{EC}^{10}$. Поскольку Северная Македония готовится к началу переговоров о вступлении в ЕС, она вполне может и дальше использовать помощь со стороны ОБСЕ государственным институтам в данных областях.

В то же время национальные власти иногда говорят о присутствии Миссии в Скопье как о поводе для беспокойства. Полевые операции ОБСЕ, развернутые исключительно в Юго-Восточной и Восточной Европе, на Южном Кавказе и в Центральной Азии, обычно рассматриваются как «поставщики услуг в условиях кризиса, переходного периода и государственного строительства» ${ }^{11}$. Правительство рассматривает тот факт, что государства-участники ОБСЕ возложили на страну ответственность за председательство в организации в 2023 г., как признание того, 
что ее безопасность больше не дает повода для беспокойства. Дальнейшее же присутствие полевой операции может повредить имиджу страны как «истории успеха».

Тем не менее, многолетний опыт работы миссии в Скопье и глубокое понимание местных потребностей и условий сделали возможной реализацию в Северной Македонии таких необходимых программ, как формирование многоэтнической полиции и мониторинг судебных процессов. ОБСЕ гибко реагировала на запросы как государственных институтов, так и гражданского общества, включая содействие в реализации решений парламента по обеспечению большей открытости и близости к избирателям, разработке правовой базы для организации и участия молодежи в принятии решений, а также работу с уязвимыми группами населения во время вспышки пандемии коронавируса. Прекращение работы полевой операции скорее всего привело бы к образованию значительных пробелов в этой деятельности. Поэтому на данный момент закрытие миссии не стоит в повестке дня правительства. Однако оно может поставить вопрос о том, чтобы в будущем в ее мандате приоритетное внимание уделялось содействию реформам в стране, а не предотвращению кризисов.

\section{ОБСЕ в восприятии гражданского общества и общественности}

ОБСЕ пользуется хорошей репутацией как в органах государственного управления, так и в гражданском обществе. Присутствие ОБСЕ на местах особенно важно для гражданского общества, поскольку его деятельность во многом зависит от внешней донорской помощи, и оно рассматривает миссию в Скопье как важного партнера. Однако осведомленность широкой общественности о деятельности ОБСЕ более ограничена. Отчасти это можно объяснить тем, что в процессе урегулирования деликатных ситуаций и посредничества между различными заинтересованными сторонами организация руководствуется правилами «тихой дипломатии» ${ }^{12}$. В отличие от подхода ЕС, в котором проведение неофициальных встреч сочетается с публичными заявлениями, призванными повлиять на общественные дискуссии и направленность принимаемых политических и стратегических решений, ОБСЕ обычно работает «за кулисами», используя свой авторитет и доступ к принимающим решения высокопоставленным лицам, которым она дает советы и рекомендации. Поэтому ее деятельность и методы, а также эффективность такого подхода часто остаются вне поля зрения общественности.

Сфера, в которой деятельность ОБСЕ пользуется безусловным признанием со стороны всех заинтересованных сторон в стране, включая широкую общественность, - это выборы. Северная Македония приглашает Бюро ОБСЕ по демократическим институтам и правам человека (БДИПЧ) для наблюдения за выборами на всех уровнях и на всех этапах их проведения. Наблюдательные миссии помогают укрепить доверие к тому, что выборы пройдут в соответствии с международными 
стандартами. Их отчеты и рекомендации обычно принимаются в качестве ориентира как правящими, так и оппозиционными партиями разных этнических групп и включаются в ежегодные отчеты о прогрессе для Европейской комиссии. В настоящее время в Северной Македонии развернулась широкая общественная дискуссия об изменении избирательной системы. Страна могла бы воспользоваться содействием БДИПЧ в ходе разработки политической реформы, утверждения инклюзивной избирательной системы, основанной на демократических стандартах, и устранения некоторых недостатков системы разделения власти, установленной охридским Рамочным соглашением.

Наконец, большой потенциал для углубления сотрудничества между гражданским обществом и ОБСЕ существует в сфере экологии. В 2019 г. при поддержке ОБСЕ в Скопье был создан Орхусский центр. Однако осведомленность о его деятельности и его влияние пока невелики ${ }^{13}$. Поскольку Северная Македония отстает в выполнении своих обязательств по достижению целей в области устойчивого развития (ЦУР) $\mathrm{OOH}^{14}$, и учитывая прямую связь между всеобъемлющим подходом ОБСЕ к безопасности и устойчивым развитием, мероприятия, проводимые Миссией в Скопье в поддержку достижения ЦУР 16 (построение миролюбивого и открытого общества в интересах устойчивого развития, обеспечение доступа к правосудию для всех и создание эффективных, подотчетных и основанных на широком участии учреждений на всех уровнях), а также ЦУР 4 (качественное образование), 5 (гендерное равенство) и 10 (сокращение неравенства) являются перспективным направлением сотрудничества ${ }^{15}$.

\section{Председательство в ОБСЕ в 2023 г.}

Решение Северной Македонии предложить свою кандидатуру на председательство в ОБСЕ в 2023 г. было продиктовано желанием поднять международный авторитет страны, продемонстрировать институциональный потенциал, ожидаемый от государства-члена НАТО, стремящегося стать членом ЕС, и внести вклад в содействие выполнению принятых в рамках ОБСЕ обязательств ${ }^{16}$. Правительство воспринимает председательство как возможность представить страну в качестве примера в таких областях, как решение проблем межэтнических отношений и урегулирование двусторонних споров, особенно на Балканах и в Восточной Европе. Однако в этих областях сохраняется ряд проблем, что может свести на нет привлекательность подхода страны для других государств-участников. Во-первых, установленная ОРС модель разделения власти позволяет политическим партиям использовать вопросы межэтнических отношений в качестве разменной монеты в борьбе за власть. Во-вторых, Преспанское соглашение, подписанное с Грецией в 2018 г., которое обязало Республику Македония изменить свое конституционное название на Северную Македонию, не приблизило страну к вступлению в ЕС, как первоначально обещало 
правительство. В-третьих, Болгария наложила вето на планы Северной Македонии начать переговоры о вступлении в ЕС из-за вопросов, связанных с национальной идентичностью страны, несмотря на то, что две страны в 2017 г. подписали договор о добрососедских отношениях.

Председательство в ОБСЕ станет для Северной Македонии самым большим вызовом в многосторонней дипломатии на сегодняшний день. От государственных институтов потребуется мобилизовать значительные ресурсы и создать инклюзивные и эффективные механизмы внутренней и внешней координации. Стране придется расширить недостаточно развитую сеть дипломатических представительств, особенно на Южном Кавказе и в Центральной Азии, и заполнить должности послов в ряде важных столиц, включая Вашингтон и Москву. Более того, несмотря на недавнюю напряженность в двусторонних отношениях, ей необходимо найти способ взаимодействия с Россией, если она хочет, чтобы ее воспринимали как «честного посредника».

\section{Выводы и рекомендации}

Хотя ОБСЕ сыграла важную роль в предотвращении конфликтов и примирении в Северной Македонии, после стабилизации обстановки и консолидации страны значение организации для нее снизилось в сравнении с ЕС и НАТО. Деятельность ОБСЕ, особенно ее Миссии в Скопье, содействует вступлению Северной Македонии в ЕС, проведению необходимых для этого реформ и достижению целей устойчивого развития ООН. Однако синергетический эффект этого взаимодействия используется недостаточно. Миссия ОБСЕ в Скопье иногда подвергается стигматизации со стороны государственных органов, а выборы являются единственной сферой, в которой деятельность ОБСЕ пользуется безусловным признанием со стороны широкой общественности. Председательство Северной Македонии в ОБСЕ в 2023 г. может способствовать повышению осведомленности об ОБСЕ в стране, укреплению международного авторитета Северной Македонии, повышению роли организации в процессе демократических преобразований и расширению политической поддержки интеграции Северной Македонии в ЕС.

В качестве председателя Северная Македония могла бы подчеркнуть особые интересы страны в рамках организации и внести свой вклад в создание «группы друзей ОБСЕ» для обсуждения новой повестки дня «Хельсинки-2025». Она могла бы воспользоваться ежегодной процедурой продления мандата Миссии ОБСЕ в Скопье для того, чтобы привлечь другие государства-участники к оценке ее достижений, организовать широкий процесс консультаций для подготовки мандата миссии на предстоящий период и расширить роль ОБСЕ в проведении реформ в стране.

Институты государственного управления Северной Македонии и Европейская комиссия могли бы извлечь пользу из осуществляемого ОБСЕ наблюдения не толь- 
ко за выборами, но и в таких сферах, как свобода СМИ, защита национальных меньшинств, реформа полиции и права человека, для обогащения ежегодных докладов о прогрессе страны. В частности, компетенции ОБСЕ и работа ее миссии в Скопье могут быть использованы для обеспечения прогресса по вопросам, относящимся к главе 10 повестки дня вступления в ЕС (СМИ), а также к главам 19 (социальная политика), 23 (основные права и судебная система), 24 (правосудие и внутренние дела) и 27 (окружающая среда).

Что касается конкретных областей политики, то в ходе реформы избирательной системы в Северной Македонии следует непосредственно учесть рекомендации БДИПЧ ОБСЕ. Орхусскому центру в Скопье следует отвести более заметную роль в разработке политики и мониторинге. Миссии ОБСЕ в Скопье следует разработать мероприятия по содействию в достижении ЦУР.

Учитывая, что страны Западных Балкан становятся все более интегрированными и взаимозависимыми, председательство Северной Македонии может способствовать не только самоутверждению страны, но и более позитивному восприятию всего региона в рамках ОБСЕ. Поскольку цели этих стран по интеграции в ЕС во многом совпадают с их обязательствами в рамках ОБСЕ, активный и продуманный подход во время председательства Северной Македонии может расширить политическую поддержку данного процесса, несмотря на существующую в ряде стран ЕС «усталость от расширения». Соответственно, формулируя свои приоритеты на предстоящее в 2023 г. председательство, правительство Северной Македонии должно координировать свои действия с другими государствами-участниками ОБСЕ на Западных Балканах, использовать председательство для продвижения их общих интересов, формирования позитивного общественного мнения о регионе в странахчленах ЕС и добиться прогресса в застопорившемся процессе интеграции в ЕС.

Внутри страны правительство должно консультироваться и сотрудничать с гражданским обществом при формулировании приоритетов своего председательства в ОБСЕ. В качестве Председателя Северная Македония должна проводить мероприятия по повышению осведомленности и значимости ОБСЕ в стране (например, общественную кампанию и мероприятия с участием молодежи или массовых организаций), а также расширению роли ОБСЕ в процессе демократических преобразований.

\section{Примечания}

1 Я хотела бы выразить благодарность респондентам, согласившимся дать мне интервью, за их ценные соображения, а также Аргиро Картсонаки, Франку Эверсу и внешним рецензентам за их комментарии к предыдущему варианту статьи.

2 Ackermann A. The Republic of Macedonia and the OSCE Preventive Diplomacy in Practice // OSCE Yearbook 1997 / IFSH (ed.). - Baden-Baden: Nomos, 1998. P. 69. 
3 См.: An End to the Beginning of War: The OSCE's Role in Conflict Prevention in Macedonia and Kosovo // Wilson Center. 2005. 9 February. URL: https://www.wilsoncenter.org/event/endto-the-beginning-war-the-osces-role-conflict-prevention-macedonia-and-kosovo.

4 См.: Ambarkov N. Features of the Macedonian Power-Sharing Model and its Future // Horizons International Scientific Journal. Vol. 19 (2016). P. 81.

См., напр.: Rogier E. The Operational Role of the OSCE in the Field of Conflict Prevention: An Assessment of the Spillover Monitor Mission to Skopje (Macedonia) // The Operational Role of the OSCE in South-Eastern Europe / V.-Y. Ghebali, D. Warner (eds.). - London: Routledge, 2001. Pp. 46-51; Ackermann A. The Prevention of Armed Conflicts as an Emerging Norm in International Conflict Management: The OSCE and the UN as Norm Leaders // Peace and Conflict Studies. - 2003. - No 1. Pp. 1-16; Stefanova B. OSCE and Balkan security // Journal of Balkan and Near Eastern Studies. - 2009. - No 1. Pp. 43-60.

См., напр.: Ghebali V.-Y. The OSCE Long-Term Missions: A Creative Tool under Challenge // Helsinki Monitor. - 2004. - No 3. Pp. 202-208; Ghebali V.-Y. The OSCE Between Crisis and Reform: Towards a New Lease on Life. Geneva Centre for the Democratic Control of Armed Forces (DCAF) Policy Paper 10. Geneva, November 2005. URL: https://www.files.ethz.ch/isn /15051/PP10_Gh\%C3\%A9bali.pdf; Brichambaut M. P. The OSCE in South Eastern Europe // Crossroads. - 2006. - No 1. Pp. 104-112.

7 См., напр., о многоэтнической полиции: Dikici A. Introducing Multi-Ethnic Policing in Macedonia: The Role of the OSCE // Review of International Law and Politics. - 2007. - No. 10. Pp. 129-146/ Об интегрированном образовании: Mastrorocco R. OSCE and Civil Society in the Western Balkans: The Road to Reconciliation // Transformation and Development / A. Mihr (ed.). - Cham: Springer, 2020. Pp. 83-100.

8 Работа над первой рассчитанной на десять лет внешнеполитической стратегией страны началась в июне 2021 г.

9 См.: Влада на Република Северна Македонија. Претседател. Мандатно писмо за министерот за надворешни работи. 3 септември 2020 година. С. 3 // Официальный сайт правительства Северной Македонии. а Zaev Z. Mandate letter to the Minister of Foreign Affairs Bujar Osmani. URL: https://vlada.mk/sites/default/files/img/mandatno_pismo_osmani.pdf.

10 См.: Enhancing the accession process - A credible EU perspective for the Western Balkans // European Commission. 2020. February. URL: https://eur-lex.europa.eu/legal-content/EN/TXT/? uri=CELEX:52020DC0057.

11 Zellner W., Evers F. et al. The Future of OSCE Field Operations (Options). OSCE Network of Think Tanks and Academic Institutions, 2014. P. 3. URL: https://osce-network.net/file-OSCENetwork/documents/The_Future_of_OSCE_Field_Operations_Options_.pdf.

12 Cм.: Kemp W. (ed.). Quiet Diplomacy in Action: The OSCE High Commissioner on National Minorities. - The Hague: Martinus Nijhoff Publishers, 2001. URL: https:/www.osce.org/files/f/ documents/6/7/78633.pdf.

13 Орхусский центр в Скопье является одним из шестидесяти с лишним центров в более чем десятке европейских стран, которые проводят кампании по выполнению Конвенции Европейской экономической комиссии ООН 1998 года о доступе к информации, участии общественности в процессе принятия решений и доступе к правосудию по вопросам, касающимся окружающей среды (Орхусская конвенция).

14 См.: North Macedonia // Sustainable Development Report. URL: https://dashboards.sdgindex.org/profiles/north-macedonia.

15 См.: Sustainable Development Goals and the OSCE // Официальный сайт ОБСE. URL: https:// www.osce.org/sustainable-development-goals. 
16 См.: Liechtenstein S. North Macedonia and Estonia are seeking the OSCE Chairmanship // Security and Human Rights Monitor. - 2020. - 29 November. URL: https://www.shrmonitor.org/north-macedonia-is-seeking-the-osce-chairmanship-in-2023/. 


\section{Об авторах}

Рустам Бурнашев - профессор Казахстанско-немецкого университета (Алматы, Казахстан). Преподавал в различных высших учебных заведениях Узбекистана и Казахстана. Занимал должности директора по аналитике и консалтингу Института политических решений (Алматы, Казахстан; 2009-2013) и заведующего сектором анализа внешней политики Института стратегических и межрегиональных исследований при Президенте Республики Узбекистан (1998-2000). В 2006-2010 гг. - приглашенный исследователь Калифорнийского университета в Беркли. Соавтор книги «Безопасность в Центральной Азии: методологические рамки анализа (военный сектор безопасности)» (2006).

Дэниел С. Гамильтон - почетный член австрийского Фонда Плана Маршалла, директор программы «Глобальная Европа» Международного научного центра имени Вудро Вильсона. Преподает в Школе перспективных международных исследований Университета Джонса Хопкинса, где руководит постдокторской программой «США, Европа и мировой порядок». Занимал должность заместителя заместителя госсекретаря по европейским делам, отвечая непосредственно за политику США в отношении ОБСЕ и вопросы трансатлантической безопасности. Среди последних публикаций: «Uncommon Cause: The Future of the OSCE» и «Europe Whole and Free: Vision and Reality».

Андрей Загорский - заведующий отделом разоружения и урегулирования конфликтов Национального исследовательского института мировой экономики и международных отношений имени Е. М. Примакова (ИМЭМО) Российской академии наук. Профессор кафедры международных отношений и внешней политики России Московского государственного института международных отношений (МГИМО), член Российского совета по международным делам, трехсторонней Комиссии по проблемам глубокого сокращения ядерных вооружений и координационного комитета Сети аналитических центров и академических институтов ОБСЕ. Занимал должности проректора МГИМО, старшего вице-президента Института Восток-Запад (Прага), преподавателя Женевского центра политики безопасности и заместителя директора Института прикладных международных исследований (Москва).

Аргиро Картсонаки защитила диссертацию в области международных отношений в Университете Бирмингема. Специализируется на вопросах сецессии и перехода от войны к миру после гражданских войн. Ее текущие исследования финансируются Институтом мира США и посвящены предотвращению возобновления гражданских 
войн. В числе последних публикаций, в том числе в соавторстве: «PAIC: a New Dataset on Political Agreements for the Termination of Intra-State Conflicts 1989-2016», «Playing with Fire: an Assessment of the EU's Approach of Constructive Ambiguity on Kosovo's Blended Conflict», «The False Hope of Remedial Secession: Theory, Law and Reality». Автор книги «Breaking Away: Kosovo’s Unilateral Secession».

Ана Крстиновска - основатель и президент северомакедонского аналитического центра ESTIMA, член Постоянного совета по внешней политике Северной Македонии. Работала советником по вопросам внешней политики. Занимала должности государственного секретаря по европейским делам в правительстве Северной Македонии и первого секретаря миссии Северной Македонии при ЕС в Брюсселе. Защитила диссертацию в области международных отношений в Университете Святых Кирилла и Мефодия в Северной Македонии, получила степень магистра в области исследований ЕС в Колледже Европы в Брюгге, Бельгия. В ее научные интересы входят вопросы государственного управления и внешней политики на Западных Балканах, в ЕС и Китае.

Лукаш Кулеса - заместитель руководителя исследований Польского института международных отношений (PISM). В 2019-2021 гг. участвовал в Инициативе по безопасности, основанной на сотрудничестве, в центре внимания которой находились вопросы ОБСЕ. В 2014-2019 гг. занимал должность директора по исследованиям Европейской сети лидерства, в 2010-2012 гг. - заместителя руководителя отдела стратегического анализа Бюро национальной безопасности Польши. Его публикации включают «Reinventing Nuclear Nonproliferation and Disarmament as Cooperative Endeavors" (CFR, 2021), «Dilemmas of Arms Control: Meeting the Interests of NATO's North-Eastern Flank» (ICDS, 2020), «Towards a more stable NATO-Russia relationship» (ELN, 2019), «The Future of Conventional Arms Control in Europe» (Survival, 2018).

Барбара Кунц - научный сотрудник Института исследований проблем мира и политики безопасности при Университете Гамбурга (IFSH) с 2019 г., где в основном занимается вопросами европейской безопасности и обороны. До прихода в институт работала во Французском институте международных отношений, Фонде Генсхагена, Фонде Бертельсманна и Центре балтийских и восточноевропейских исследований. Изучала политологию и международные отношения в парижском Институте политических исследований (Sciences Po). Во время обучения в докторантуре была приглашенным научным сотрудником Центра трансатлантических отношений Школы перспективных международных исследований Университета Джонса Хопкинса (Вашингтон). Защитила диссертацию в Стокгольмском университете.

Ларс-Эрик Лундин - шведский дипломат (1976-1996), занимавшийся вопросами политики безопасности, в том числе в СБСЕ-ОБСЕ (1984-1986 и 1990-1996 гг.). 
Защитил диссертацию в области политологии и международных отношений. В 1996-2009 гг. работал в Европейской комиссии, в 2009-2011 гг. - на должности посла ЕС в ОБСЕ. Является почетным научным сотрудником Стокгольмского международного института исследования проблем мира (SIPRI) и избранным членом Шведской королевской академии военных наук. В 2019 г. подготовил для Швеции официальную экспертизу Договора о запрещении ядерного оружия. Автор справочника «Handbook on EU and Security» (2015), соавтор книг о южном измерении европейской безопасности (2020) и шведской политике безопасности $(2021$, готовится к изданию).

Гирай Садык - основатель и директор Центра европейских исследований Университета имени Йылдырыма Беязита, (Анкара, Турция), где он занимает должности профессора и заведующего кафедрой международных отношений факультета политологии. Получил стипендию им. Эйзенхауэра римского Оборонного колледжа НАТО, был постдокторантом Университета Мальме, Швеция. Защитил диссертацию в области политологии в Университете Джорджии, США, специализируясь на международных отношениях и сравнительной политологии. Исследования последнего времени посвящены европейской безопасности и внешней политике, в основном - евроатлантическим стратегиям противодействия терроризму и гибридным угрозам.

Ирина Черных - профессор Казахстанско-немецкого университета (Алматы, Казахстан). Кандидат политических наук (1995 г.) и доктор исторических наук (2007 г.). Занимала должности главного научного сотрудника Казахстанского института стратегических исследований при Президенте Республики Казахстан (2011-2020), руководителя отдела прикладного анализа Института политических решений (2009-2010) и заведующей кафедрой регионоведения и мировой экономики Казахского национального университета им. аль-Фараби (2007-2009).

Франк Эверс - научный сотрудник Института исследований проблем мира и политики безопасности при Университете Гамбурга (IFSH) и заместитель руководителя Центра исследований ОБСЕ (CORE), курирующий проекты, связанные с ОБСЕ. Работал советником Бюро ОБСЕ в Ереване и заместителем главы Миссии ОБСЕ в Украине в Симферополе (Крым). Был одним из инициаторов создания Орхусского центра в Ереване и внес большой вклад в учреждение Академии ОБСЕ в Бишкеке, Дипломатической школы Армении, Сети аналитических центров и академических институтов ОБСЕ, а также специальных курсов для будущих председателей ОБСЕ. В сферу его интересов входит широкий круг вопросов: от деятельности ОБСЕ по урегулированию конфликтов до проблем транснациональной безопасности в восточнославянских странах, на Южном Кавказе и в Центральной Азии. 
